\title{
7. DIAGENETIC ENVIRONMENTS OF AUTHIGENIC CARBONATES AND OPAL-CT CRYSTALLIZATION IN LOWER MIOCENE TO UPPER OLIGOCENE DEPOSITS OF THE NORWEGIAN SEA (ODP SITE 643, LEG 104) ${ }^{1}$
}

\author{
Rüdiger Henrich ${ }^{2}$
}

\begin{abstract}
Different generations of complex authigenic carbonates formed in siliceous muds (lithologic Unit IV) and hemipelagic clays (lithologic Unit V) of ODP Site 643, Leg 104 Norwegian Sea. The dominant phase in Unit IV is an early diagenetic Mn, Fe-calcite with a strong negative $\delta{ }^{13} \mathrm{C}\left(-14\right.$ to $-16 \%$ signature, and slightly negative $\delta{ }^{18} \mathrm{O}$ values. The strong negative $\delta{ }^{13} \mathrm{C}$ results from extensive incorporation of ${ }^{12} \mathrm{C}$-enriched $\mathrm{CO}_{2}$ derived from bacterial degradation of marine organic matter into early $\mathrm{Mn}, \mathrm{Fe}-$ calcite cements. Concomitant framboidal pyrite precipitation and abundant SEM microtextures showing excellent preservation of delicate structures of fragile diatom valves by outpourings with early Mn-calcites strongly support their shallow burial formation before the onset of compaction.

Later generations of authigenic mineralizations in lithologic Unit IV include minor amounts of a second generation of calcite with platy crystals, possibly precipitated along with opal-A dissolution, and finally opal-CT crystallization in deeper seated environments overgrowing earlier precipitates with films and lepispheres. The last mineralization is collophane (fluor apatite) forming amorphous aggregates and tiny hexagonal crystals. Authigenic mineral assemblages in lithologic Unit V consist of rhodochrosites, transitional rhodochrosite/manganosiderites, and apatite. A negative $\delta{ }^{13} \mathrm{C}$ $(-7.1$ to $-15.6 \%)$ and a fluctuating $\delta{ }^{18} \mathrm{O}$ signal indicates that the micritic to sparitic rhodochrosites, transitional rhodochrosites/manganosiderites were formed at various burial depths. $\mathrm{CO}_{2}$ resulted from organic matter degradation in the lowermost sulfate reduction zone and from biogenic methane generation in the lowermost sediments, resulting in variable and negative $\delta{ }^{13} \mathrm{C}$ signals. The change in carbonate mineralogy reflects major compositional differences compared to sediments in Unit IV. Most prominent is an increase in altered ash as a primary sediment component and a sudden decrease of siliceous microfossils. Upward diffusion of cations, lowered salinities in pore waters, and elevated temperatures provide diagenetic environments favoring increased remobilization processes.
\end{abstract}

\section{INTRODUCTION}

Shipboard scientists were first puzzled by the rapid change in lithology between Units III and IV of Site 643, represented by a marked contrast between fossil-rich siliceous lower Miocene deposits rapidly passing into compaction-laminated, extremely fossil-poor muds to mudstones below $290 \mathrm{mbsf}$. The occurrence of various semilithified to indurated carbonate layers, bands, and a few concretions at discrete levels within these latter otherwise monotonous lithologies gave the first evidence of authigenic carbonate formation, possibly reflecting a strong diagenetic overprint of the sediments (Eldholm, Thiede, Taylor, et al., 1987).

The purpose of this study is to carefully describe the various generations of authigenic carbonates and concomitant mineralizations, to discuss sources of the various elements of the precipitates, to elucidate the succession of early diagenetic and early burial processes, and finally, to present some major suggestions for a revised paleoceanographic interpretation of the sediments.

The formation of authigenic carbonates in organic matterrich sediments has been well documented by numerous workers. Recent summaries of the various occurences are provided by the synthesis studies of Coleman (1985), Curtis and Coleman (1986), and Hesse (1986). The anaerobic microbial degradation of organic matter, of which immature marine organic material is most reactive, was found to be the most important mechanism

${ }^{1}$ Eldholm, O., Thiede, J., Taylor, E., et al., 1989. Proc. ODP, Sci. Results, 104: College Station, TX (Ocean Drilling Program).

2 Geologisch-Paläontologisches Institut Universität Kiel, Olshausenstr. 40, D $2300 \mathrm{Kiel}$, Federal Republic of Germany; now at GEOMAR, Forschungszentrum für Marine Geowissenschaften an der Universität Kiel, Wischhofstr. 1-3, D-2300 Kiel, Federal Republic of Germany. for the precipitation of authigenic carbonates. Depending on the availability and exhaustion of various oxidizing agents, microbial degradation processes commonly are determined by a succession of environments, first summarized in the diagenetical zonal scheme by Curtis (1977). Aerobic oxidation is followed by manganese, nitrate, and iron reduction, and finally by sulfate reduction. These reactions are succeeded by two processes that separate reduced and oxidized carbon species, e.g., microbial methanogenesis and abiological decarboxylation of organic compounds. Authigenic carbonate, precipitated in each of these diagenetic zonal environments, reveals its characteristic carbon and oxygen isotopic composition (Claypool and Kaplan, 1974; Curtis, 1977; Irwin, 1980; Kelts and McKenzie, 1982; Pisciotto and Mahoney, 1981).

From aerobic oxidation through anaerobic sulfate reduction, a shift toward negative $\delta{ }^{13} \mathrm{C}$ values as low as $-21 \%$ is found because of $\mathrm{CO}_{2}$ production by degradation of marine organic matter $\left(\delta{ }^{13} \mathrm{C}\right.$ typically -20 to $-21 \%$ ). Positive $\delta{ }^{13} \mathrm{C}$ values are characteristic of the methane generation zone because of ${ }^{12} \mathrm{C} \mathrm{de}$ pletion in the remaining $\mathrm{CO}_{2}$ during methanogenesis. Negative ${ }^{13} \mathrm{C}$ values are characteristic of thermocatalytic decarboxylation because of thermocatalytic degradation of marine organic matter. The oxygen isotopic values may be used to estimate formation temperatures and to distinguish the anaerobic sulfate reduction and thermocatalytic decarboxylation zones.

The $\mathrm{pH}$ and buffering of pore water is another important factor during authigenic carbonate precipitation (Hesse, 1986). A relatively high $\mathrm{pH}$ buffered by reactions other than those of the carbonate system itself was found to favor authigenic carbonate precipitation. In anoxic environments $\mathrm{pH}$ buffering predominantly takes place by hydrogen sulfide as well as hydrogen ion uptake by the reduction of manganese oxides and manganese hydroxides in the nitrate reduction zone (and iron oxides/ hydroxides in the sulfate reduction zone, respectively) resulting 
in authigenic carbonate precipitation (Suess, 1979). If the $\mathrm{pH}$ is controlled by the carbonate system, as commonly observed in oxic environments, an increased $\mathrm{P}_{\mathrm{CO} 2}$ due to organic matter oxidation may raise the bicarbonate activity and thus cause carbonate dissolution.

Factors modifying the schematic zonation of diagenetic environments are the variability of sedimentation rates, strongly in fluencing the time of transpassing through the different diagenetic environments during burial (Pisciotto and Mahoney, 1981), and the availability of the various oxidizing agents, especially iron and manganese oxides/hydroxides, limiting or reenforcing the maintenance of one or the other diagenetic environment.

Figure 1 displays the most common authigenic carbonates observed in the various diagenetic environments. The Peedee belemnite (PDB) standard is used. In DSDP drill sites, calcite and dolomite are the most abundant authigenic carbonates observed (e.g., Leg 63: Pisciotto and Mahoney, 1981; Leg 64: Kelts and McKenzie, 1982; Leg 66: Wada et al., 1981; Leg 76: Matsumoto, 1983). The occurrence of rhodochrosite, siderite, and complex transitions between the two endmembers has only been described from a few DSDP drill sites (e.g., Hein et al., 1979; Leg 56: Okada 1980; Leg 66: Wada et al., 1981; Leg 93: von Rad and Botz, 1987). In this paper, the occurrences of manganese/iron-rich calcites, rhodochrosites, and transitional rhodochrosite/siderites at Site 643 are described along with a discussion of the mechanisms and sources of their formation.

\section{METHODS}

All carbonate concretions and thin bands observed during shipboard visual core descriptions were sampled and investigated in the same manner. A few small slices of each semilithified-to-indurated sample were mounted on a SEM carrier for SEM/EDAX investigations. Microtextures were studied on clean broken surfaces without any other treatment. Carbonate mineralogies were analysed using a calibrated Phillips PW 1050 diffractometer with $\mathrm{Co}-\mathrm{K} \alpha$ radiation. Carbonate and organic carbon percentages were partly derived from shipboard results [compare Eldholm, Thiede, Taylor, et al. (1987), Table 10, p. 489]. All values in the authigenic carbonates were measured by a shore-based infrared gas analyser. This instrument uses a photometric determination, e.g., infrared absorption of $\mathrm{CO}_{2}$ released from a sample after extraction of carbonate in $30 \%$ phosphoric acid solution. Accuracy of these measurements is very high, with a standard deviation of less than $0.1 \%$ for both

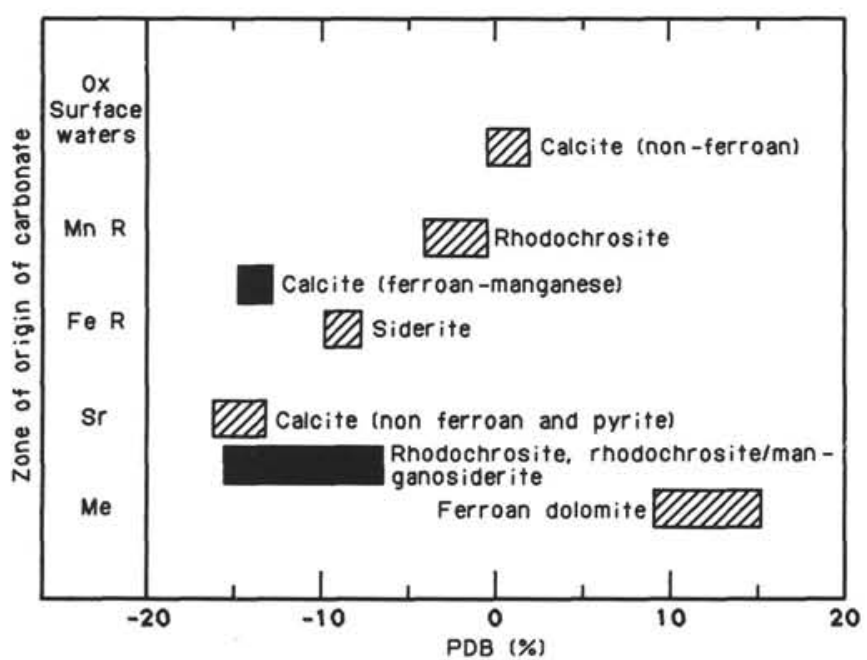

Figure 1. Carbon isotopic composition of authigenic carbonates related to the zone of formation ( $\mathrm{MnR}=$ manganese reduction, $\mathrm{FeR}=$ iron reduction, $\mathrm{SR}=$ sulfate reduction, $\mathrm{Me}=$ methanogeneses; modified from Coleman, 1985). Carbon isotopic composition of authigenic carbonates investigated is indicated by dark bars. organic carbon and carbonate contents. Because of the presence of noncalcitic carbonate minerals we extracted the carbonate in $33 \%$ phosphoric acid solution under a pressure of 3 bars and a temperature of $140^{\circ} \mathrm{C}$. Carbon- 13 and oxygen- 18 isotopic ratios were determined with a Micromass VG $602 \mathrm{~V}$ mass spectrometer having an online preparation device, at the carbon-14 Laboratory of the University of Kiel. $\mathrm{CO}_{2}$ gas samples were prepared from the carbonate using the traditional phosphoric acid method (McCrea, 195O). Appropriate correction factors were applied (Craig, 1957) on results expressed as per mil deviation from the PDB isotopic standard. No correction of the rhodochrosite $\delta{ }^{18} \mathrm{O}$ values were applied as the acid-fractionation factor relative to bicarbonate is unknown. Element compositions of the carbonates, especially $\mathrm{Mg}, \mathrm{Fe}, \mathrm{Mn}, \mathrm{Sr}$, and $\mathrm{K}$ contents, were measured by atomic absorption spectrophotometry after extraction of carbonate in concentrated hydrochloric acid solution. Phosphorus contents were determined spectrophotometrically by averaging phosphormolybdate complex (Strickland and Pearson, 1968) after digestion of sediment by hydrofluoric/hydrochloric/nitric acid treatment.

\section{RESULTS}

\section{Sediments and Mode of Occurrence of Authigenic Carbonates}

At Site 643 we drilled through $174 \mathrm{~m}$ of lower Miocene, highly biogenic siliceous deposits of lithologic Unit III, mainly diatom oozes and siliceous muds (Eldholm, Thiede, Taylor, et al., 1987), into $126 \mathrm{~m}$ of monotonous, partly siliceous, extremely fossil-poor lower Miocene mudstones of lithologic Unit IV (compare Fig. 2). The degree of consolidation changed rapidly between Units IV and V. Compaction lamination and a high degree of drilling disturbance with typical drilling biscuits dominates the character of the sediment in both units. Preservation of sedimentary structures was, under these conditions, very poor. The only clearly recognizable sedimentary structures were compacted burrows, some of them identifiable as Zoophycos. Dark sediment colors, high organic carbon contents $(0.8$ to $3 \%$, Fig. 3) and common pyritized burrow tubes suggest a predominant anoxic pore-water environment for sediments of lithologic Unit IV. Shipboard smear-slide analysis (Eldholm, Thiede, Taylor, et al., 1987) reveals that fossil content of these mudstones is almost restricted to a few siliceous manganese-encrusted microfossils, mainly sponge spicules and a few diatoms. XRD results indicate almost complete conversion of opal-A to opal-CT (Fig. 4). Poorly preserved calcareous microfossils occur only in very thin discrete bands restricted to certain intervals.

Unit V mainly contains varicolored, often color-banded and -laminated claystones, most of which are extremely compaction-laminated. An increasing amount of altered volcanic ash beds, reworked pyroclastic rocks, and thick welded and compacted pumicestones were recorded from the basal parts of Unit V. Smear-slide analyses frequently reflect considerable contents of goethite, hematite, and glauconite as well as pyrite. Measured organic carbon contents are generally low in Unit V in contrast to high contents in Unit IV (Fig. 3). There is a change in siliceous mineralogies. Opal-CT disappears in these sediments (Fig. 4), but terrestrially derived quartz and feldspar become more abundant (compare Froget et al., this volume). Sparse calcareous nannofossil (Donnally, this volume) and planktonic foraminifers (Spiegler and Jansen, this volume) and abundant palynomorph (Manum et al., this volume) biostratigraphic data indicate an early Miocene age for Unit IV, a late Oligocene age for the upper part of Unit V, and an Oligocene/Eocene age for the lower part of Unit V (see stratigraphic summary of Goll, this volume).

Carbonate lithologies are intercalated in these monotonous mudstones of Units IV and V. In most cases, authigenic carbonates occur as semilithified thin discrete bands or, more rarely, as completely hardened layers (Table 1); both are commonly only several centimeters thick. Concretionary growth was observed in 


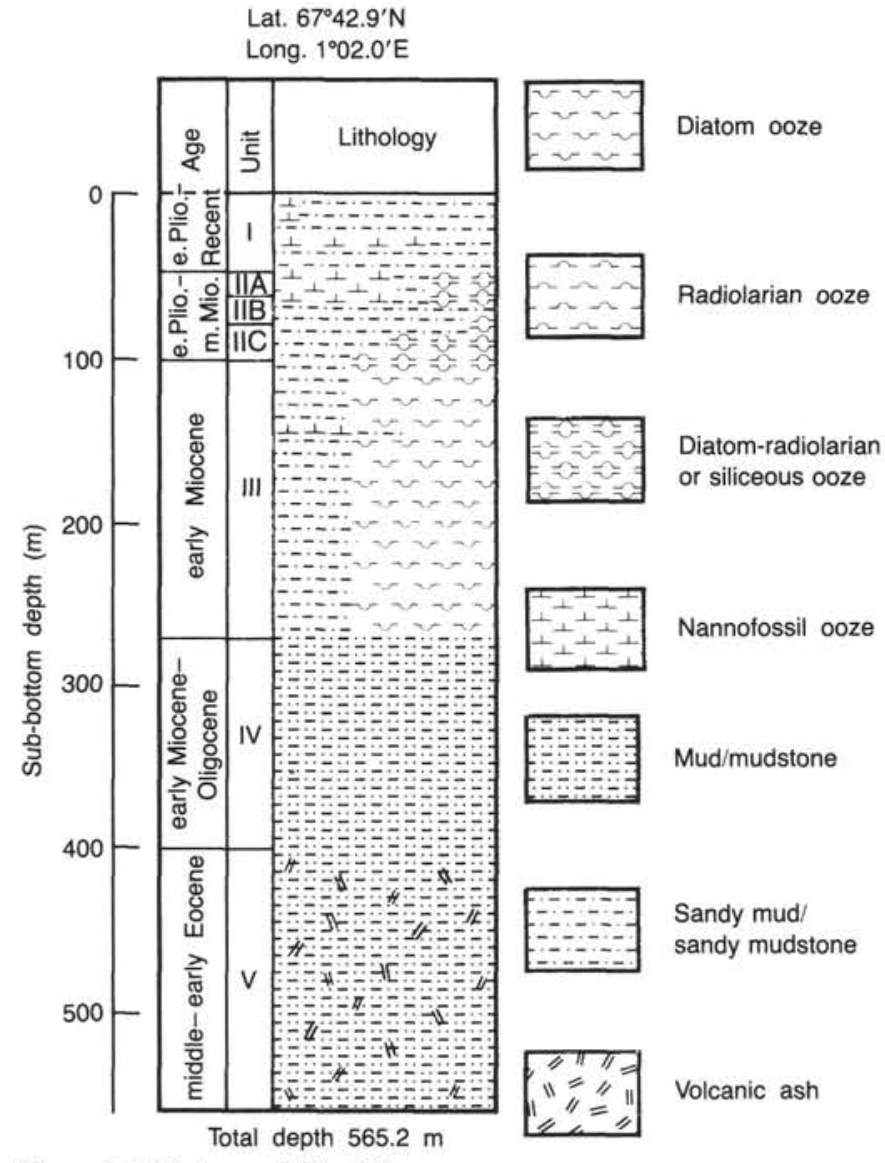

Figure 2. Lithology of Site 643.

one instance, Core 104-643A-47X. Most of these carbonate layers are extremely fine-grained micrites (less than $1 \mu \mathrm{m}$ ). Coarser crystalline hardened carbonate bands occur only within Cores 104-643A-48X, -643A-51X, and -643A-52X. Whitish crystal aggregates, frequently noted by the Shipboard Scientific Party, are interpreted as incipient authigenic carbonate concretions. Considerable amounts of calcareous microfossils were only found in a very few of these hardened layers, e.g., in Samples 104-643A$32 \mathrm{X}-03,120-130 \mathrm{~cm}$, as well as in Samples 104-643A-42X-03, $77-80 \mathrm{~cm}$ and $-643 \mathrm{~A}-43 \mathrm{X}-\mathrm{CC}, 0-40 \mathrm{~cm}$. In all other cases, calcareous microfossils are reported as minor unidentifiable traces by the shipboard biostratigraphers. Shore-based SEM investigations detected significant amounts of coccoliths only in samples from Cores 104-643A-42X and -643A-43X.

All basic evidence from preliminary shipboard analysis indicates that most of the carbonate bands recovered are authigenic precipitates. Exceptions are the bands of Cores 104-643A-42X and $-643 \mathrm{~A}-43 \mathrm{X}$, which have formed by in situ dissolution/precipitation processes.

\section{Carbonate Mineralogy, Element Composition, and Oxygen/Carbon Isotopes}

Figure 4 shows the distribution of calcite, rhodochrosite, apatite, and opal-CT vs. depth in the cores, along with carbonate content and element concentrations ( $\mathrm{Fe}, \mathrm{Mn}, \mathrm{Mg}$ ) of the carbonate, and the amount of phosphorus in the carbonate horizons. All values determined are listed in Table 2. A clear shift in both carbonate and noncarbonate mineralogy, and in major-element contents, between 409.8 and 415.8 mbsf coincides with the boundary of lithologic Units IV and V at $400 \mathrm{mbsf}$. In the upper part, the carbonate mineralogy is exclusively calcitic with both rather pure calcites and strongly $\mathrm{Mn}$ - and Fe-enriched calcites, while in the lower part rhodochrosite and transitional rhodochrosite/manganosiderite are recorded. Additionally, Unit IV is characterized by the presence of opal-CT, which disappears in Unit V at 416 mbsf. Element concentrations measured by atomic absorption spectrophotometry (AAS) are in good accordance with characteristic shifts of d-values of calcites and rhodochrosites determined by XRD analysis (compare Fig. 4, Table 3). These shifts indicate considerable substitution for Ca predominantly by $\mathrm{Mn}$ and $\mathrm{Fe}$ and to a lesser extent by $\mathrm{Mg}$ in the calcites, and $\mathrm{Ca}$ and $\mathrm{Fe}$ in the rhodochrosites. Rhodochrosites reveal two phases. The first phase records $104 \mathrm{~d}$-values around 2.85 to 2.86 , indicating an excess of $\mathrm{Ca}$. The second phase shows $104 \mathrm{~d}$ values of 2.82 to 2.83 referring to an enrichment of Fe. Corresponding measurements of Fe and Mn with AAS (Fig. 4) indicate the same trend. Elevated phosphorus concentrations and precipitation of collophane (fluor apatite; Table 2) were detected at various levels in both units.

Results of $\delta{ }^{13} \mathrm{C}$ and $\delta{ }^{18} \mathrm{O}$ measurements are displayed in Figure 5 . The dominantly very negative $\delta{ }^{13} \mathrm{C}$ values varying between -12 and $-16 \%$ are only interrupted by a shift towards less negative values between 390 and 440 mbsf. At 394 to 416 mbsf high contents of primary carbonates, e.g., badly preserved coccoliths and strongly corroded tests of planktonic foraminifers, were detected. Thus the higher $\delta{ }^{13} \mathrm{C}$ values of the calcites $(-0.6 \%$ to $-5.3 \%$ ) in this section represent relatively pure marine biogenic carbonate with admixtures of a minor portion of ${ }^{12} \mathrm{C}$-enriched $\mathrm{CO}_{2}$, probably derived from microbial oxidation of organic matter.

No definite trend is seen in the $\delta{ }^{18} \mathrm{O}$ signal. It shifts between -4.8 and and $+2.5 \%$. The $\delta{ }^{18} \mathrm{O}$ values of $\mathrm{Mn}$ - and Fe-calcites in the upper section are relatively constant, ranging between -1.3 and $+0.5 \%$ with exception of Section 104-643A-32XCC, $12 \mathrm{~cm}(+2.5 \%)$. For a calcite with a $\delta^{18} \mathrm{O}$ value of +2.5 $\%$, a formation temperature of $2^{\circ} \mathrm{C}$ is attained using the equation of Shackleton and Kennett (1975) and assuming precipitation in equilibrium with pore water of 34 to $35 \%$ salinity ( $\delta$ ${ }^{18} \mathrm{O}_{\mathrm{w}}=-1 \%$ SMOW). One may speculate that these temperatures reflect near sea floor conditions. Applying the same calculation on the most negative $\delta^{18} \mathrm{O}$ value, i.e., $-1.3 \%$, a formation temperature of $16.5^{\circ} \mathrm{C}$ is attained. Use of the geothermal gradient $0.078^{\circ} \mathrm{C} / \mathrm{m}$ (Eldholm, Thiede, Taylor, et al., 1987), results in $185 \mathrm{mbsf}$ formation depth. If lowered pore-water salinities are assumed as well, a much shallower formation depth may be considered. Hence, all calcites were precipitated at sub-bottom levels shallower than 185 mbsf. The more negative and fluctuating values in $\delta{ }^{18} \mathrm{O}$ in the lower section (Unit V) indicate more complex processes that have operated at variable burial depths. Shipboard pore-water analyses (Fig. 6) show a decrease in salinity by almost $3 \%$, which might partly account for the more negative $\delta{ }^{18} \mathrm{O}$ signal. Using the geothermal gradient of $0.078^{\circ} \mathrm{C} / \mathrm{m}$, a temperature range of $31^{\circ}$ to $39^{\circ} \mathrm{C}$ can be expected at 400 to $500 \mathrm{mbsf}$. For calcites in equilibrium with the present pore water $\left(31^{\circ}\right.$ to $39^{\circ} \mathrm{C}, 32 \%$ salinity $-\delta{ }^{18} \mathrm{O}_{\mathrm{w}}=$ -1.3 SMOW $\% 0$ ) a $\delta{ }^{18} \mathrm{O}$ of -4.7 to $-6.3 \%$ is calculated using the equation of Shackleton and Kennett (1975). This is close to the most negative $\delta{ }^{18} \mathrm{O}(-2.7,-4.9 \% 0)$ measured in the rhodochrosites and transitional rhodochrosite/manganosiderites. The heaviest $\delta{ }^{18} \mathrm{O}$ value, $+2.3 \%$, determined at $416 \mathrm{mbsf}$ (Table 2), resulted from contribution of primary carbonates during rhodochrosite formation. Indications are relicts of coccoliths (SEM evidence) and the shift in the $\delta{ }^{13} \mathrm{C}$ signal discussed earlier. It has to be stressed again that no corrections of the rhodochrosite $\delta{ }^{18} \mathrm{O}$ values were applied as the acid fractionation factor is unknown. Consequently the above calculations have to 


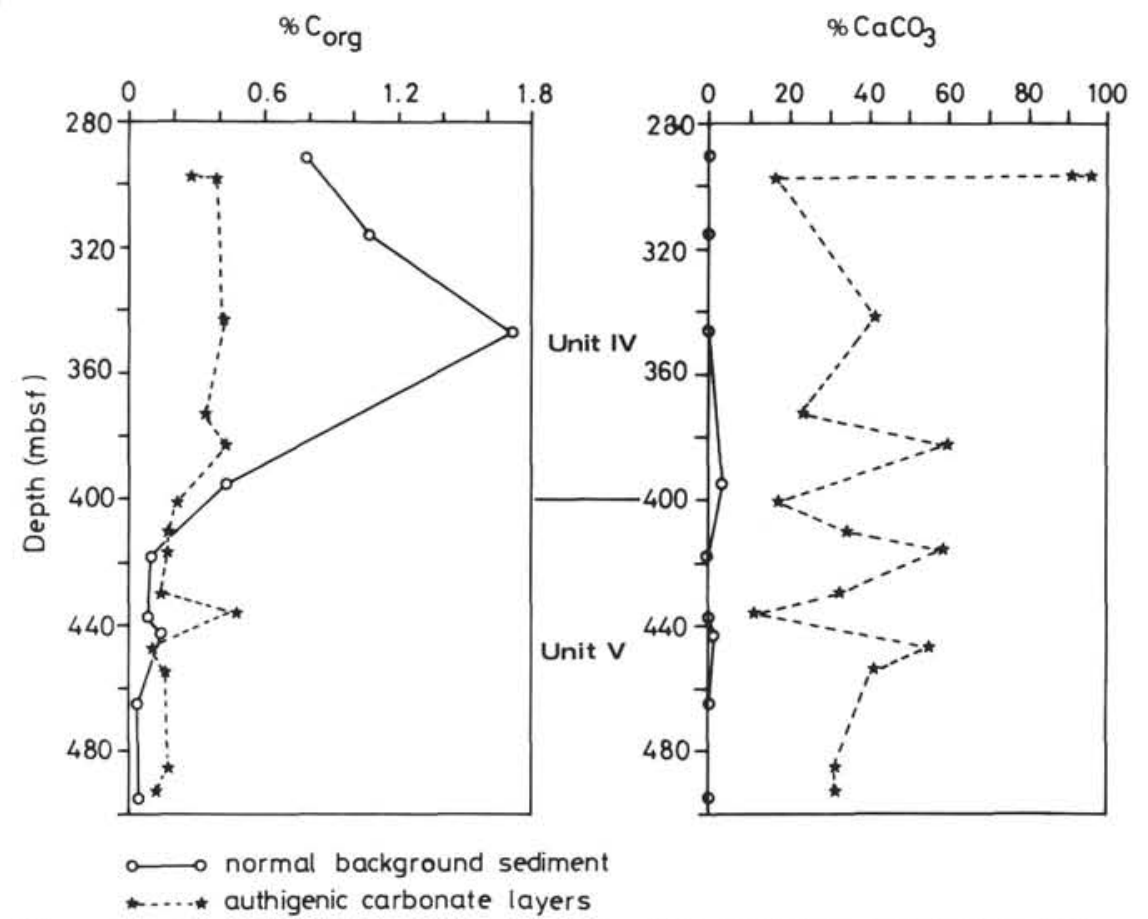

Figure 3. Carbonate and organic carbon contents of Site 643 lithologic Units IV and V.

be considered with caution, but it seems obvious that a formation during deeper burial at elevated temperatures is indicated for some of the rhodochrosites (compare von Rad and Botz, 1987).

Pore-water analyses (Fig. 6) record significant amounts of sulfate $(24$ to $12 \mathrm{mmol} / \mathrm{L}$ ) down to $500 \mathrm{mbsf}$, authigenic carbonate occurrences covering the entire interval. Thus sulfate reduction has not yet resulted in a complete consumption of sulfate in the upper $500 \mathrm{~m}$ of the sediment column. Alternatively, one may assume that sulfate has been renewed by lateral or downcore diffusion. Methane contents are generally very low (5 to $8 \mathrm{ppm}$ ) in the upper section and show an increase below 430 mbsf ( 8 to $13 \mathrm{ppm}$ ). As a consequence, today biogenic methane is contributed to the pore fluids in considerable amounts only in the lowermost section of the bore hole. Calcium and magnesium profiles are inversely correlated, reflecting a downcore decrease in magnesium and increase in calcium. This $\mathrm{Ca} / \mathrm{Mg}$ concentration gradient may be explained either by diffusion (Hesse 1986) or may indicate increased supply of alteration products from basement or from ash disseminated within the sediment column (Hein, 1979).

In conclusion, the more negative but fluctuating $\delta{ }^{18} \mathrm{O}$ values of the rhodochrosites, a gradual downcore decrease in pore-water sulfate, and a correlated increase in biogenic methane (Kvenvolden et al., this volume) suggest that the rhodochrosites and transitional rhodochrosite/manganosiderites precipitated in the transition of the sulfate reduction and the methane generation zone. A depletion in sulfate and an increase in biogenic methane, possibly derived from upward diffusion from deeper levels, are observed in this zone. Variations in the negative $\delta{ }^{18} \mathrm{O}$ values reflect different formation depths and contribution of primary carbonates by dissolution/reprecipitation processes. Consistent changes in $\delta{ }^{13} \mathrm{C}$ indicate a stepwise increase of $\delta^{13} \mathrm{C}$ as would be expected if increased amounts of $\mathrm{CO}_{2}$ derived from methane generation were admixed in the pore fluids.

\section{Microtextures of Early Diagnetic Cement Fabrics}

An early precipitation of authigenic carbonate cements in lithologic Unit IV resulted in excellent preservation of siliceous microfossils, which in contrast are almost completely dissolved in the surrounding mudstones. These manganese and iron-rich calcites may be developed as a hypidiomorphic to xenomorphic micrite cement matrix, but more frequently form xenomorphic crystals completely matching pores of siliceous microfossils. Endocasts and casts of diatom valves by $\mathrm{Mn} / \mathrm{Fe}$-rich calcites reveal a perfect resolution of almost any structural detail such as, for example, the original cibrum structure of the areolae of a valve of Endictya spp. displayed in Plates 1.1 and 1.2. Different slices of sediment investigated in the SEM record a dense packing of siliceous microfossils, e.g., predominantly large centric diatom valves (Plate 2.2). Intact chains of valves of Melosira sp. were also observed (Plate 2.1). Large densely packed valves of Ethmodiscus sp., replaced by carbonate, seem to be completely unaffected by compaction (Plate 2.5 ), indicating a very early formation of these authigenic carbonates. No relicts of calcareous microfossils could be detected in the siliceous samples with SEM, even though they were carefully searched. Biogenic opal has been completely removed during later stages, e.g., during early burial. Dissolved silica afterward reprecipitated when porewater chemistry was favorite-filling pore spaces within the sediment and microfossil pores (compare Kastner and Gieskes, 1983).

Well-developed opal-CT lepispheres are found predominantly in the more pure authigenic carbonate layers, while in marly horizons opal-CT tends to crystallize along thin, irregular films (Kastner, 1981). Plates 3.1, 3.2 display the typical appearance of opal-CT lepispheres precipitated on both primary microfossilreplacement carbonate and on a second generation of carbonate with elongated prismatic needles.

Only the samples in Core 104-643A-42 contain considerable amounts of coccoliths within lithologic Unit IV. They are embedded in a very fine-grained (less than $1 \mu \mathrm{m}$ ), strongly dissolved micritic matrix (Plates 4.3, 4.4). Siliceous microfossils in these samples are less abundant. Dispersed occurrence of 5 to $10-\mu \mathrm{m}$ large idiomorphic Fe-Mn-rich calcite rhombs [EDAX $(\mathrm{Ca}, \mathrm{Fe}, \mathrm{Mn})]$ reflects precipitation of a later generation of cement. Altogether, microfabrics in these samples may be interpreted as recording primarily dissolution/reprecipitation processes in a nannofossil-rich sediment layer. 


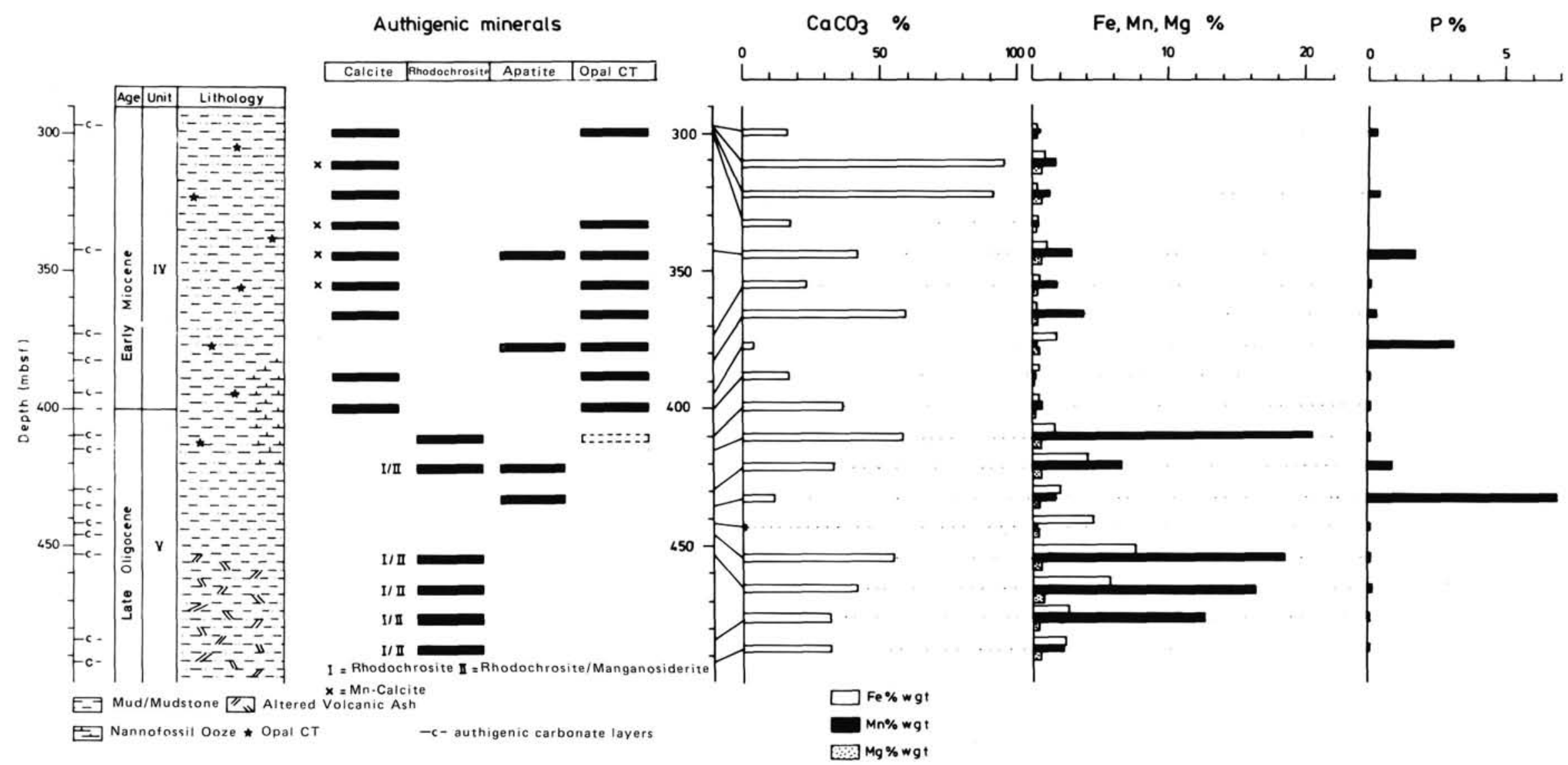

Figure 4. Distribution of authigenic mineralizations and element concentrations in authigenic carbonates in Site 643A lithologic Units IV and V. 
Table 1. Lithologic description of authigenic carbonate layer at Site 643.

\begin{tabular}{|c|c|c|c|c|}
\hline $\begin{array}{l}\text { Sample } \\
\text { core-section } \\
\text { interval }\end{array}$ & $\begin{array}{l}\text { Depth } \\
\text { (mbsf) }\end{array}$ & $\begin{array}{l}\text { Bed } \\
\text { thickness } \\
(\mathrm{cm})\end{array}$ & Lithology & Authigenic carbonates \\
\hline $\begin{array}{l}32-\theta 3-126 \\
32-\theta 3-143 \\
32-c c-84 \\
32--c c-12\end{array}$ & $\begin{array}{l}297.52 \\
297.73 \\
297.84 \\
297.92\end{array}$ & $\begin{array}{r}10 \\
18 \\
5 \\
2\end{array}$ & $\begin{array}{l}\text { Recrystallized siliceous } \\
\text { nanno ooze and calcareous } \\
\text { mudstone, light brownish } \\
\text { gray (2.5Y6/29) to grayish } \\
\text { brown with compaction } \\
\text { lamination }\end{array}$ & $\begin{array}{l}\text { Calcite, Mn-calcite; } \\
\text { numerous outpoorings of siliceous } \\
\text { microfossils }\end{array}$ \\
\hline $37-61-12$ & 342.42 & 15 & $\begin{array}{l}\text { Calcareous mudstone, } \\
\text { light olive brown }(2.5 Y \\
5 / 4) \text {, completely lithified }\end{array}$ & $\begin{array}{l}\text { Mn-calcite, collophane; } \\
\text { carbonate replaced siliceous microfossils } \\
\text { in a strongly dissolved micritic matrix }\end{array}$ \\
\hline $4 \theta-c c-48$ & 372.45 & 4 & $\begin{array}{l}\text { Calcareous mudstone, brown } \\
\text { (10YR5/3), homogenous } \\
\text { with minor pyrite }\end{array}$ & $\begin{array}{l}\text { Mn-calcite, } \\
\text { carbonate replaced siliceous microfossils } \\
\text { in a strongly dissolved micritic matrix }\end{array}$ \\
\hline $41-c c-38$ & 382.38 & 7 & $\begin{array}{l}\text { Calcareous mudstone, } \\
\text { yellowish brown (10YR5/4), } \\
\text { completely lithified. }\end{array}$ & $\begin{array}{l}\text { Mn-calcite, numerous outpoorings } \\
\text { of siliceous microfossils }\end{array}$ \\
\hline $\begin{array}{l}42-83-73 \\
42-c c-48\end{array}$ & $\begin{array}{l}394.48 \\
480.48\end{array}$ & $\begin{array}{l}3 \\
6\end{array}$ & $\begin{array}{l}\text { Recrystallized chalk and } \\
\text { calcareous mudstone, light } \\
\text { gray }(5 Y 6 / 1) \text { and yellowish } \\
\text { brown }(10 Y R 5 / 4)\end{array}$ & $\begin{array}{l}\text { Calcite, collophane : } \\
\text { Badly preserved coccoliths in a strongly } \\
\text { dissolved micrite matrix }\end{array}$ \\
\hline $43-c c-18$ & 489.78 & 42 & $\begin{array}{l}\text { Recrystallized chalk and } \\
\text { calcareous mudstone, } \\
\text { greenish gray (5GY4/1) and } \\
\text { yellowish brown }(10 Y R 5 / 4) \text {. } \\
\text { minor burrowing }\end{array}$ & $\begin{array}{l}\text { Calcite, collophane ; } \\
\text { Badly preserved coccoliths in a strongly } \\
\text { dissolved micrite matrix }\end{array}$ \\
\hline $44-84-125$ & 415.78 & 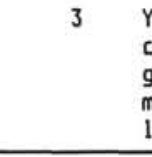 & $\begin{array}{l}\text { Yellowish brown (18YR5/4) } \\
\text { concretion embedded in dark } \\
\text { greenish gray ( } 56 Y 5 / 1) \\
\text { mottled and compaction } \\
\text { laminated claystone }\end{array}$ & $\begin{array}{l}\text { Rhodochrosite, very fine grained } \\
\text { micritic matrix, dispersed diffuse } \\
\text { large rhodochrosite rhombs }\end{array}$ \\
\hline $45-c c-34$ & 429.4 & 4 & $\begin{array}{l}\text { Calcareous mudstone light } \\
\text { gray }(2.5 Y 7 / 2)\end{array}$ & $\begin{array}{l}\text { Rhodochrosite; Rhodochrosite/Manganoside- } \\
\text { rite, Collophan; very fine grained } \\
\text { micritic matrix; dispersed with large } \\
\text { rhodochrosite-rhombs, tiny apatite } \\
\text { crystals }\end{array}$ \\
\hline $46-85-38$ & 435.78 & 2 & $\begin{array}{l}\text { Mudstone grayish brown } \\
(2.5 Y 5 / 2)\end{array}$ & $\begin{array}{l}\text { Collophane concretions with tiny apatite } \\
\text { crystals }\end{array}$ \\
\hline $47-86-28$ & 446.88 & c & $\begin{array}{l}\text { background sediment" in } \\
\text { unit } U \text {, mudstone dark brown } \\
(7.5 Y R 3 / 2) \text {, dark reddish } \\
\text { brown }(5 Y R 3 / 2) \text { mottled and } \\
\text { bioturbated; coarse } \\
\text { crystal-rich calcareous } \\
\text { concretion }\end{array}$ & $\begin{array}{l}\text { Rhodochrosite, Rhodochrosite/Manganoside- } \\
\text { rite, large xenomorphic to hypidio- } \\
\text { morphic crystals }\end{array}$ \\
\hline $48-84-89$ & 454.89 & 6 & $\begin{array}{l}\text { Coarse crystal-rich } \\
\text { calcareous mudstone }\end{array}$ & $\begin{array}{l}\text { Rhodochrosite, Rhodochrosite/Manganoside- } \\
\text { rite, large xenomorphic to hypidio- } \\
\text { morphic crystals }\end{array}$ \\
\hline $51-05-105$ & 484.75 & 2 & $\begin{array}{l}\text { Coarse crystal-rich } \\
\text { calcareous mudstone }\end{array}$ & $\begin{array}{l}\text { Rhodochrosite, Rhodochrosite/Manganoside- } \\
\text { rite; Mn rich alumosilicates in altered } \\
\text { ash aggregates }\end{array}$ \\
\hline $52-84-57$ & 492.37 & 1 & $\begin{array}{l}\text { Coarse crystal-rich whitish } \\
\text { calcareous mudstone }\end{array}$ & $\begin{array}{l}\text { Rhodochrosite, Rhodochrosite/Manganoside- } \\
\text { rite, large xenomorphic to hypidio- } \\
\text { morphic crystals }\end{array}$ \\
\hline
\end{tabular}

The complete succession of diagenetic mineralizations most commonly found in samples from lithologic Unit IV are nicely summarized by Plate 4.2. A first generation of authigenic carbonate outpouring siliceous microfossils was precipitated along with framboidal pyrite. The latter served as substrate for a second generation of carbonate with about $10-\mu \mathrm{m}$-sized platy crystals which in turn were overgrown by films and lepispheres of opal-CT. The last mineralization is collophane (flour apatite), not documented in Plate 4.2 , forming amorphous aggregates and tiny hexagonal crystals (Plates $1.3,1.4$ ).
The clear shift in carbonate mineralogy observed between lithologic Units IV and V is further substantiated by differences in microfabric. Badly preserved siliceous microfossils could only rarely be detected in the samples from the authigenic carbonate layers in Unit V. The most common microfabric is a very finegrained, strongly dissolved micrite matrix dispersed with a few large idiomorphic rhodochrosite or transitional rhodochrosite/ manganosiderite rhombs. In addition, small clasts of possibly altered ash fragments were observed. Plate 3.4 shows their typical appearance consisting of densely packed bundles of elon- 
Table 2. Carbonate-, organic carbon-, trace element contents and oxygen/carbon stable isotopes of authigenic carbonates at Site 643.

\begin{tabular}{|c|c|c|c|c|c|c|c|c|c|c|c|}
\hline Sample & $\begin{array}{l}\text { Depth } \\
\text { (mbsf) }\end{array}$ & Carb.min & $\begin{array}{c}\mathrm{Fe} \\
\text { wgt. } \mathrm{x}\end{array}$ & $\begin{array}{c}M n \\
\text { wgt. } \%\end{array}$ & $\begin{array}{c}\mathrm{Mg} \\
\text { wgt. } \%\end{array}$ & $\begin{array}{c}\mathrm{Sr} \\
\text { wgt. } \%\end{array}$ & $\begin{array}{c}\text { P } \\
\text { wgt. }\end{array}$ & $\begin{array}{l}\mathrm{CaCO3} \\
\text { wgt. } \%\end{array}$ & $\begin{array}{c}\text { TOC } \\
\text { wgt.\% }\end{array}$ & $\begin{array}{l}{ }^{13} \mathrm{C} \\
\% . \mathrm{PDB}\end{array}$ & $\begin{array}{c}180 \\
\times . P D B \\
\end{array}$ \\
\hline 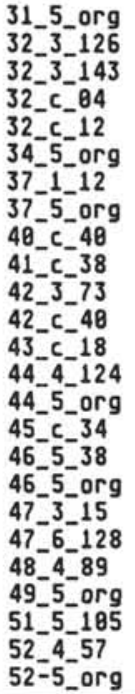 & $\begin{array}{l}291.80 \\
297.52 \\
297.73 \\
297.84 \\
297.92 \\
315.80 \\
342.42 \\
346.78 \\
372.45 \\
382.38 \\
394.48 \\
488.48 \\
489.78 \\
415.78 \\
417.58 \\
429.46 \\
435.78 \\
436.99 \\
442.25 \\
446.88 \\
454.89 \\
464.48 \\
484.75 \\
492.37 \\
494.80\end{array}$ & $\begin{array}{l}\text { calcite } \\
\text { Mn-calc. } \\
\text { Mn-calc. } \\
\text { Mn-calc. } \\
\text { Mn-calc. } \\
\text { Mn-calc. } \\
\text { Mn-calc. } \\
\text { calcite } \\
\text { calcite } \\
\text { calcite } \\
\text { rhod.I } \\
\text { rhod.I/II }\end{array}$ & $\begin{array}{l}8.29 \\
0.93 \\
0.33 \\
0.48 \\
1.02 \\
0.48 \\
8.24 \\
1.84 \\
0.46 \\
0.48 \\
1.55 \\
3.91 \\
1.97 \\
4.34 \\
7.45 \\
5.78 \\
2.68 \\
2.36\end{array}$ & $\begin{array}{r}0.38 \\
1.63 \\
1.23 \\
8.48 \\
2.72 \\
1.67 \\
3.95 \\
0.25 \\
0.17 \\
0.77 \\
28.46 \\
\\
6.34 \\
1.57 \\
0.23 \\
18.34 \\
16.38 \\
12.49 \\
2.28\end{array}$ & $\begin{array}{l}0.26 \\
0.77 \\
0.62 \\
0.29 \\
0.56 \\
0.42 \\
0.39 \\
0.58 \\
0.17 \\
0.21 \\
0.57 \\
0.66 \\
0.50 \\
0.40 \\
0.60 \\
0.72 \\
0.43 \\
0.49\end{array}$ & $\begin{array}{l}0.02 \\
0.05 \\
0.03 \\
0.02 \\
0.03 \\
0.02 \\
0.84 \\
0.05 \\
0.81 \\
0.01 \\
0.03 \\
0.08 \\
0.08 \\
0.08 \\
0.00 \\
0.00 \\
0.80 \\
0.00\end{array}$ & $\begin{array}{l}0.27 \\
0.37 \\
1.72 \\
0.88 \\
0.30 \\
3.18 \\
0.03 \\
0.13 \\
0.88 \\
0.91 \\
6.87 \\
0.85 \\
0.10 \\
0.15 \\
0.88 \\
0.84\end{array}$ & $\begin{array}{r}8.84 \\
16.28 \\
95.28 \\
91.36 \\
17.31 \\
8.93 \\
41.99 \\
0.04 \\
23.39 \\
59.68 \\
3.66 \\
17.05 \\
34.64 \\
58.46 \\
8.09 \\
32.73 \\
18.91 \\
0.03 \\
0.79 \\
54.70 \\
41.12 \\
0.84 \\
31.17 \\
31.16 \\
0.82\end{array}$ & $\begin{array}{l}0.80 \\
0.27 \\
0.30 \\
0.28 \\
0.39 \\
1.08 \\
0.42 \\
1.72 \\
0.34 \\
0.43 \\
0.43 \\
0.21 \\
0.17 \\
0.17 \\
0.11 \\
0.14 \\
0.48 \\
0.09 \\
0.14 \\
0.10 \\
0.16 \\
0.05 \\
0.17 \\
0.12 \\
0.05\end{array}$ & $\begin{array}{l}-13.64 \\
-15.84 \\
-14.83 \\
-16.18 \\
-16.75 \\
-0.58 \\
-2.29 \\
-5.29 \\
-18.42 \\
-9.35 \\
-7.88\end{array}$ & $\begin{array}{r}-0.93 \\
-1.27 \\
2.53 \\
0.58 \\
-0.71 \\
-0.84 \\
-8.13 \\
-1.03 \\
2.25 \\
-0.57 \\
-4.86\end{array}$ \\
\hline
\end{tabular}

Table 3. X-ray diffraction results on authigenic carbonates in Hole 643A.

\begin{tabular}{|c|c|c|c|c|c|c|c|c|c|c|c|c|}
\hline \multicolumn{13}{|c|}{ RHODOCHROSITE } \\
\hline \multirow{2}{*}{\multicolumn{3}{|c|}{ Standard }} & \multirow{2}{*}{\multicolumn{2}{|c|}{$45-c c-34$}} & \multicolumn{6}{|c|}{ Saaple [ Core - Section - Interval (ca) ] } & \multirow{2}{*}{\multicolumn{2}{|c|}{$52-04-57$}} \\
\hline & & & & & $47-06$ & & 48-04- & & $51-05$ & & & \\
\hline hkl & d & I & d & I & $d$ & I & $d$ & 1 & $d$ & 1 & $d$ & 1 \\
\hline \multirow{2}{*}{102} & 3.66 & 35 & 3.67 & 27 & 3.66 & 13 & 3.67 & 16 & 3.67 & 23 & 3.67 & 48 \\
\hline & & & 3.62 & 28 & & & & & & & & \\
\hline \multirow[t]{2}{*}{104} & 2.84 & 100 & 2.86 & 100 & 2.85 & 100 & 2.86 & 100 & 2.86 & 100 & 2.86 & 100 \\
\hline & & & 2.82 & 100 & 2.82 & 100 & 2.83 & 100 & & & & \\
\hline \multirow[t]{2}{*}{110} & 3.39 & 20 & 2.40 & 32 & 2.39 & 12 & 2.39 & 17 & 2.40 & 24 & 2.40 & 56 \\
\hline & & & 2.34 & 35 & 2.34 & 13 & 2.38 & 17 & & & & \\
\hline \multirow[t]{2}{*}{113} & 2.17 & 25 & 2.18 & 31 & 2.18 & 11 & 2.18 & 16 & 2.18 & 25 & 2.18 & 50 \\
\hline & & & 2.13 & 31 & 2.15 & 22 & 2.17 & 19 & & & & \\
\hline
\end{tabular}

Calcite//nn-Calcite

\begin{tabular}{|c|c|c|c|c|c|c|c|c|}
\hline \multirow{2}{*}{\multicolumn{2}{|c|}{ Standard }} & & & \multirow[b]{2}{*}{$\begin{array}{l}32-03-126 \\
\text { Calcite }\end{array}$} & \multicolumn{3}{|c|}{ Saaple [ Core - Section - Interval (ca) ] } & \multirow[b]{2}{*}{$\begin{array}{l}37-01-12 \\
\text { Mn-Calcite }\end{array}$} \\
\hline & & & & & $\begin{array}{l}32-03-143 \\
\text { Hn-Calcite }\end{array}$ & $\begin{array}{l}32-c c-04 \\
\text { Mn-Calcite }\end{array}$ & $\begin{array}{l}32-c c-12 \\
\text { Mn-Caicite }\end{array}$ & \\
\hline hkl & $d$ & 1 & & d & d & d & d & d \\
\hline 102 & 3.86 & 12 & & 3.86 & 3.85 & 3.85 & 3.85 & 3.85 \\
\hline 104 & 3.04 & 100 & & 3.04 & 3.02 & 3.20 & 3.03 & 3.02 \\
\hline 110 & 2.50 & 14 & & 2.51 & 2.48 & 2.49 & 2.48 & 2.48 \\
\hline \multirow[t]{11}{*}{113} & 2.29 & 18 & & 2.28 & 2.27 & 2.27 & 2.28 & 2.27 \\
\hline & & & & & Sauple & e - Section & arval (ca) I & \\
\hline & & & & $40-\mathrm{cc}-40$ & $41-\mathrm{Cc}-38$ & $43-c c-18$ & & \\
\hline & & & & Mn-Calcite & Mn-Calcite & Calcite & & \\
\hline & & & hkl & $d$ & $d$ & $d$ & & \\
\hline & & & 102 & 3.83 & 3.85 & 3.86 & & \\
\hline & & & 104 & 3.02 & 3.02 & 3.04 & & \\
\hline & & & 110 & 2.48 & 2.48 & 2.49 & & \\
\hline & & & & 2.47 & & & & \\
\hline & & & 113 & 2.28 & 2.27 & 2.28 & & \\
\hline & & & & 2.27 & & & & \\
\hline
\end{tabular}




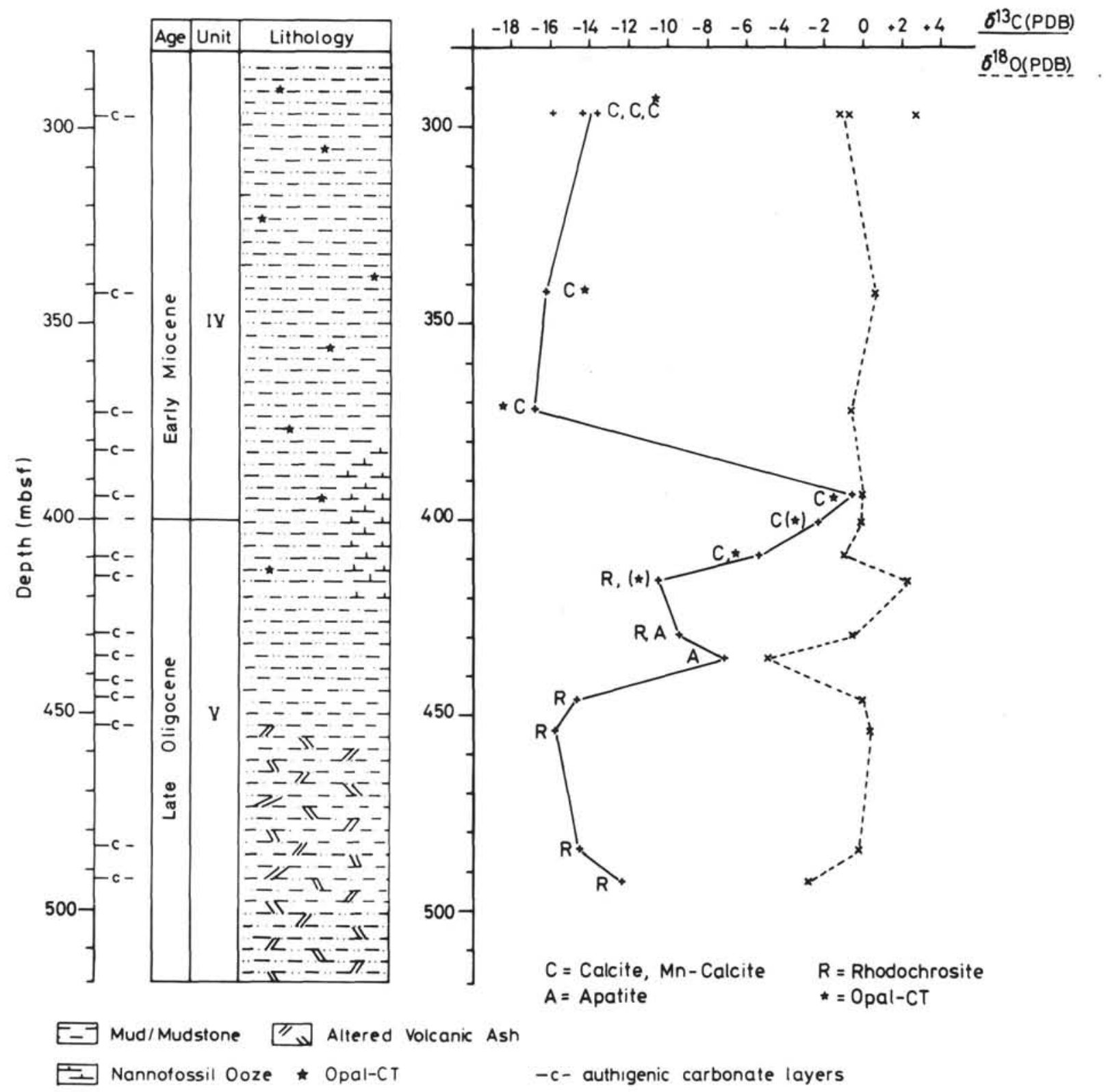

Figure 5. Carbon and oxygen isotopes of authigenic carbonates from Site 643 lithologic Units IV and V.

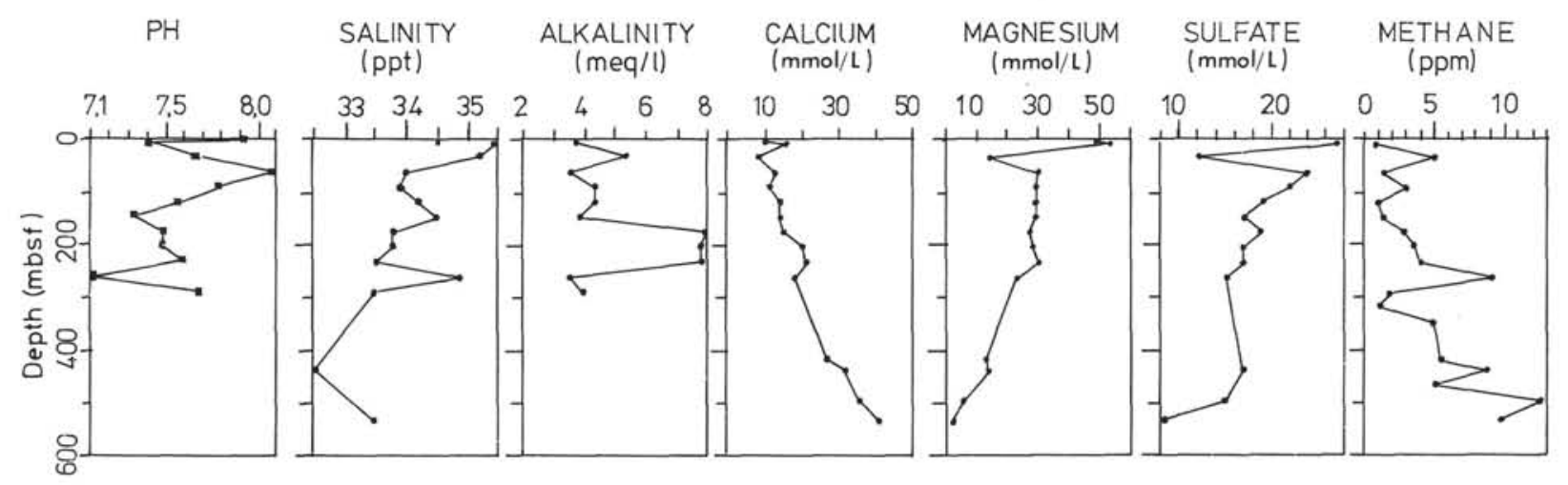

Figure 6. Pore-water chemistry of Site 643 sediments. 
gated Mn-rich aluminosilicate rods, possibly representing MnFe-rich zeolites (EDAX: Fe, Mn, Ca, Si, Al). Collophane forms a monomineralogic concretion at $435.78 \mathrm{mbsf}$, but also appears in larger amounts in a authigenic carbonate layer at 429.40 mbsf. In the latter case, typical tiny collophan crystals were precipitated on idiomorphic to hypidiomorphic rhodochrosite rhombs.

\section{DISCUSSION}

Authigenic carbonate may form in a great variety of diagenetic environments. It is now well established that most of the complex authigenic carbonates form preferentially in organicrich sediments, which were either deposited under reducing conditions or became reduced shortly after sedimentation (references cited in Hesse, 1986). The authigenic Mn-, Fe-calcites described in this study formed under similar conditions. The concomitant occurrence of framboidal pyrite in the authigenic calcitic layers indicates formation in the anoxic sulfidic zone according to the classification of Berner (1981). This is further substantiated by carbon isotopic data which record a constantly negative signal $\left(-14\right.$ to $-16 \%$ ), indicating that ${ }^{12} \mathrm{C}$-enriched $\mathrm{CO}_{2}$ derived from bacterial degradation of marine organic matter during sulfate reduction was the most prominent source of $\mathrm{CO}_{2}$. Deviations in $\delta{ }^{18} \mathrm{O}$ from the normal sea water-derived signal might indicate slight differences in formation depths and/or variations in pore-water salinity. In addition to concomitant pyrite occurrence, negative carbon isotope values and a rather constant slightly negative $\delta{ }^{18} \mathrm{O}$ signal, abundant microtextural indications, e.g., an excellent preservation of structural details of siliceous microfossil without any sign of compaction, clearly document early formation of authigenic carbonate layers in the upper tens of meters (maximum is $185 \mathrm{mbsf}$ ) of the sediment column.

The rhodochrosites and transitional rhodochrosites/manganosiderites reflect more complex diagenetic environments in the section below 415 mbsf. Formation at various levels of shallow and deeper burial down to the present sub-bottom depth is suggested by their fluctuating, but generally negative oxygen isotopic signals. A combination of elevated temperatures, decrease in pore-water salinity, and increased supply of alteration products from disseminated ash in the lowermost sediment column most probably caused the variation in the measured isotopic signal. SEM microtextures give no indications of shallow burial cement features, but commonly reflect diagenetic overprinting. Measured sulfate and methane concentrations in pore waters suggest that most of the rhodochrosites formed in the lowermost transition of the sulfate reduction zone. This zone shows a strong decrease in sulfate and an increase in biogenic methane derived by upward diffusion from deeper levels (compare with Tasse and Hesse, 1984).

Different sources of iron and manganese might be envisaged for the early Fe-Mn-calcites and the late rhodochrosites. Principally, four major pools must be considered. $\mathrm{Mn}$ and $\mathrm{Fe}$ might be mobilized in considerable amounts from organic-matter-rich sediment facies (Tasse and Hesse, 1984). Gieskes (1981) discussed a release of manganese into pore water during opal-A dissolution. Hein et al. (1979) presented evidence of cation input into early diagenetic pore waters by alteration processes of ash beds. Fourth, increased input of terrestrial derived manganese and iron oxides/hydroxides into the sediments might occur due to mobilization in reducing environments. Manganese input by opal-A dissolution as a mechanism is supported by the high content of siliceous microfossils in Unit III. Additionally, high organic carbon contents in background sediments are recorded in the same interval (compare Fig. 3). Therefore, a major source for cations in this part of the section may be degradation of organic matter and degradation of siliceous microfossils. Addi- tionally, a certain amount of altered ash might have contributed $\mathrm{Mn}$ and $\mathrm{Fe}$. High contents of ferromagnesium smectites and ferromagnesium illite were observed in the clay mineral assemblages (Froget et al., this volume). Additionally, glauconites interpreted as alteration products of volcanic ash were observed (Eldholm, Thiede, Taylor, et al., 1987; Despraries et al. and Froget et al., this volume). Minor amounts of recrystallized nannofossil carbonate have contributed at certain intervals (Table 1).

The characteristic change in composition of the background sediment in Unit V, e.g., the high contents of goethite, hematite, and glauconite, the low organic carbon values, the disappearance of opal-CT, the increase in terrestrially derived quartz and feldspar (Froget et al., this volume) and frequent occurrence of altered ash fragments provides different sources of cations. The most important mechanism of cation supply for authigenic rhodochrosites in Unit V is an intensive remobilization and upward diffusion of cations during deeper burial at elevated temperatures from various sources in the sediments of Unit V, e.g., an increased input from terrigenous sources and reworked volcaniclastics indicating a shift in the paleoceanographic setting toward a hemipelagic continental margin environment. Unit V sediments portray enhanced organic matter degradation processes relative to Unit IV.

Authigenic Fe-Mn-calcites formed very early before compaction of the sediment occurred. Only minor amounts of a secondary generation of later calcites were precipitated, possibly along with opal-A dissolution in Unit IV. Opal-CT crystallization might have taken place during compaction when alkalinity increased (Williams and Crerar, 1985). Phosphorus was concentrated in pore water over a long time span and finally precipitated as the last mineralization.

\section{PALEOENVIRONMENT}

Unit IV sediments were classified as monotonous terrigenous mudstones, in contrast to the highly productive biogenic siliceous oozes and muds in Unit III above (Eldholm, Thiede, Taylor, et al., 1987). Microtextural evidence detected in early diagenetic authigenic Fe-Mn-calcite layers described in this study clearly documents that a highly productive biogenic siliceous environment prevailed throughout lithologic Unit IV and that a significant loss of siliceous microfossils in the mudstones was caused by opal-A dissolution and later opal-CT crystallization during early burial and compaction (see also results of Froget et al., this volume). Furthermore, the high abundance of diatoms, especially large centric diatoms, detected in the authigenic carbonate layers may indicate a prevalence of siliceous blooms in surface waters. Siliceous blooms most probably were triggered by enhanced river supplied nutrients under warm humid climatic conditions (compare Henrich et al., this volume).

Biostratigraphic data indicate an early Miocene age throughout Unit IV and a late Oligocene age in the upper portion of Unit V. Thus prominent differences in primary sediment composition resulting in a different diagenetic overprinting between these two units almost coincide with a main stratigraphic boundary. No indications of significant amounts of siliceous microfossils or their diagenetic remanents could be found in sediments of Unit V. A similar shift of siliceous microfossil contents was detected by Bjørklund (1976) in unconsolidated sediments at Site 338 (Leg 38) and attributed to a reduced flux of skeletal debris to the sea floor during Oligocene time. Considerable amounts of calcareous microfossils, including coccoliths and planktonic and calcareous benthic foraminifers, appear in the youngest upper Oligocene sediments of Site 643. High amounts of dinocysts indicate a continuation of oceanic conditions (Manum et al., this volume), and a rich arenaceous benthic foraminifer fauna records a bathyal environment. Additionally, an increase in reworked volcanogenic clastics is recorded. In summary, Site 643 
may have shifted from a bathyal hemipelagic mud environment during late Oligocene to biogenic-siliceous deposition during the early Miocene. Rivers-supplied nutrients might have been considerably lower due to a more arid climate on the surrounding continents in late Oligocene. In contrast, processes of reworking might have been enhanced during the late Oligocene low sea level stand.

\section{CONCLUSIONS}

1. Authigenic carbonate layers in lithologic Units IV and V at Site 643 reveal distinct downcore variations in carbonate mineralogies and their major-element compositions. Carbonate precipitation changed from early $\mathrm{Mn}$, Fe-rich calcites in Unit IV to late rhodochrosites and transitional rhodochrosites/manganosiderites in Unit V, indicating a downcore enrichment of manganese and iron incorporated in the carbonate cements.

2. Early cementation of Mn-, Fe-calcite cements favored an excellent preservation of delicate structural details of siliceous microfossils, especially of diatom valves in Unit IV. High organic carbon contents in the background sediments, concomitant occurrence of framboidal pyrite as well as a constantly very negative $\delta{ }^{13} \mathrm{C}(-14$ to $-16 \%$ ) and a predominantely slightly negative $\delta{ }^{18} \mathrm{O}(-1.3$ to $-0.1 \%)$ signal indicate an early authigenic formation of these cements within the sulfate reduction zone.

3. High amounts of recrystallized nannofossil carbonate result in a $\delta{ }^{13} \mathrm{C}$ shift toward less negative values in the lowermost section of Unit IV.

4. A negative $\delta{ }^{13} \mathrm{C}(-7.1$ to $-15.6 \%$ ) and a fluctuating $\delta$ ${ }^{18} \mathrm{O}$ signal indicates that micritic to sparitic rhodochrosites and transitional rhodochrosites/manganosiderites were formed at various burial depths. $\mathrm{CO}_{2}$ was provided by degradation of organic matter in the lowermost sulfate reduction zone and by biogenic methane generation in the lowermost sediments, resulting in the observed variably negative $\delta{ }^{13} \mathrm{C}$ signals. The change in carbonate mineralogy reflects major compositional differences compared to sediments in Unit IV. Most prominent is an increase in altered ash as a primary sediment component and a sudden decrease of siliceous microfossils. Upward diffusion of cations, lowered pore-water salinities, and elevated temperatures provide diagenetic environments favoring increased remobilization processes.

5. Silica, enriched during early burial dissolution of opal-A following authigenic carbonate precipitation, and phosphorus, derived from the degradation of organic matter, were precipitated after considerable compaction had occurred. Typical opalCT lepispheres crystallized in more pure authigenic carbonate bands, while marly layers reveal films of poorly crystallized opal-CT. Collophane with tiny crystals and amorphous aggregates is the last mineralization found.

6. Environmental interpretations by the shipboard scientific party (Eldholm, Thiede, Taylor, et al., 1987) are partly revised. Unit IV records a highly productive, biogenic siliceous environment, which is only preserved in the early authigenic carbonate layers. Siliceous blooms may possibly be caused by a high nutrient supply from rivers and may indicate a more humid climate on the surrounding continents. Unit V records a bathyal hemipelagic clay environment strongly influenced by resuspension of organic matter and by a strong input of reworked volcaniclastic material. These processes may have been enhanced during the late Oligocene low sea level stand.

\section{ACKNOWLEDGMENTS}

I thank Captain Oonk and the crew of the JOIDES Resolution for their dedicated service during Leg 104. Thanks to the shipboard technical and scientific party for good cooperation and stimulating discussions. G. Bohrmann, R. Botz, and P. Stoffers read drafts of the manu- script and made numerous valuable suggestions. The review by $\mathrm{U}$. von Rad essentially improved the manuscript. I am indebted to $\mathrm{H}$. Erlenkeuser and H. Cordt at the Carbon-14 Laboratory, University of Kiel, for providing the isotopic data to $\mathrm{H}$. Lange for determination of carbonate phases by XRD, and to J. Fenner for determination of diatom species. Technical assistance by U. Drechsler (chemical analysis), W. Reimann (operation of the SEM), C. Henrich (draftings), and U. Schuldt (photographic assistance) is gratefully acknowledged. This study was supported by grants from the German Research Foundation (DFG project Th 200/3-4). This is publication No. 29 of the Special Research Project (SFB 313) at the University of Kiel.

\section{REFERENCES}

Berner, R. A., 1981. A new geochemical classification of sedimentary environments. J. Sediment. Petrol., 44: 260-261.

Bjørklund, K. R., 1976: Radiolaria from the Norwegian Sea, Leg 38 of the Deep Sea Drilling Project. In Talwani, M., Udintsev, G., et al., Init. Repts. DSDP, 38: Washington (U.S. Govt. Printing Office), 1101-1168.

Claypool, G. E., and Kaplan, I. R., 1974. The origin and distribution of methane in marine sediments. In Kaplan, I. R. (Ed.), Natural Gases in Marine Sediments. Marine Science, Vol. 3: New York (Plenum Press), 99-139.

Craig, H., 1957. Isotopic standards for carbon and oxygen and correction factors for mass spectrometric analysis of carbon dioxide. Geochim. Cosmochim. Acta, 12: 133-149.

Coleman, M. L., 1985. Geochemistry of diagenetic non-silicate minerals: Kinetic considerations. Philos. Trans. R. Soc. London, A315, 39-56.

Curtis, C. D., 1977. Sedimentary geochemistry: environments and processes dominated by involvement of an aqueous phase. Philos. Trans. $R$. Soc. London, A286, 353-372.

Curtis, C. D., Coleman, M. L., 1986. Controls on the precipitation of early diagenetic calcite, dolomite and siderite concretions in complex depositional sequences. Soc. Econ. Paleontol. Mineral. Spec. Publ., 38: $23-33$.

Eldholm, O., Thiede, J., Taylor, E., et al., 1987. Proc. ODP, Init. Repts., 104: College Station, TX (Ocean Drilling Program).

Gieskes, J. M., 1981. Deep sea drilling interstitial water studies: Implications for chemical alteration of the ocean crust, Layers I and II. In Warme, J. E., Douglas, R. G., and Winterer, E. L. (Eds.), The Deep Sea Drilling Project: A decade of progress. Soc. Econ. Paleontol. Mineral. Spec. Publ. 32: 149-167.

Hein, J. R., O'Neil, J. R., and Jones, M. G., 1979. Origin of authigenic carbonates in sediment from the deep Bering Sea. Sedimentology, 27: 577-591.

Hesse, R., 1986. Early diagenetic pore water/sediment interaction: Modern offshore basins. Geoscience Canada, 13: 165-196.

Irwin, H., 1980. Early diagenetic carbonate precipitation and pore fluid migration in the Kimmeridge clay of Dorset, England. Sedimentology, 27: 577-591.

Kastner, M., 1981. Authigenic silicates in deep-sea sediments: formation and diagenesis. In Emiliani, C. (Ed.), The Sea, Vo.7, 915-980.

Kastner, M., and Gieskes, J. M., 1983. Opal-A to opal-CT transformation: a kinetic study. In Iijima, A., Hein, J. R., and Siever, R. (Eds.), Siliceous deposits in the Pacific Ocean. Dev. Sedimentol., Vol. 36, 211-227.

Kelts, K., and McKenzie, J. A., 1982. Diagenetic dolomite formation in Quarternary anoxic diatomaceous muds of Deep Sea Drilling Project Leg 64, Gulf of California. In Curray, J. R., Moore, D. G., et al., Init. Repts DSDP, 64, Pt. 2: Washington (U.S. Govt. Printing Office), 553-569.

Matsumoto, R., 1983. Mineralogy and geochemistry of carbonate diagenesis of the Pliocene and Pleistocene hemipelagic mud on the Blake Outer Ridge, Site 533, Leg 76. In Sheridan, R. E., Gradstein, F. M., et al., Init. Repts. DSDP, 76: Washington (U.S. Govt. Printing Office), 411-427.

McCrea, J. M., 1950. The isotopic chemistry of carbonates and a paleotemperature scale. J. Chem. Phys., 18: 849-857.

Okada, H., 1980. Pebbles and carbonate nodules from Deep Sea Drilling Project Leg 56 cores. In Scientific Party, Init. Repts. DSDP, 5657, Pt. 2: Washington (U.S. Govt. Printing Office), 1089-1105.

Pisciotto, K. A., and Mahoney, J. J., 1981: Isotopic survey of diagenetic carbonates, Deep Sea Drilling Project Leg 63. In Yeats, R. S., Haq, 
B. U., et al., Init. Repts DSDP, 63: Washington (U.S. Govt. Printing Office), 595-609.

von Rad, U., and Botz, R., 1987. Authigenic Fe-Mn carbonates in Cretaceous and Tertiary sediments of the continental rise off eastern North America, Deep Sea Drilling Project Site 603. In Van Hinte, J. E., Wise, S. W., Jr., et al., Init. Repts. DSDP, 93: Washington (U.S. Govt. Printing Office), 1061-1077.

Shackleton, N. J., and Kennett, J. P., 1975. Paleotemperature history of the Cenozoic and the initiation of Antarctic glaciation: Oxygen and carbon isotope analyses in DSDP Sites 277,279 , and 281 . In Kennett, J. P., Houtz, R. E., et al., Init. Repts. DSDP, 29: Washington (U.S. Govt. Printing Office), 743-755.

Strickland, J. D. H., and Parsons, T. R., 1968: A handbook of sea water analysis. Bull. Fish. Res. Board Can., 167.

Suess, E., 1979. Mineral phases formed in anoxic sediments by microbial decomposition of organic matter. Geochim. Cosmochim. Acta, 43: $339-352$.
Tasse, N., and Hesse, R., 1984: Origin and significance of complex authigenic carbonates in Cretaceous black shales of the Western Alps. J. Sediment. Petrol., 54: 1012-1027.

Wada, H., Niitsuma, N., Nagasawa, K., and Okada, H., 1981. Deep sea carbonate nodules from the Middle America trench area off Mexico, Deep Sea Drilling Project Leg 66. In Watkins, J. S., Moore, J. C., et al., Init. Repts. DSDP, 66: Washington (U.S. Govt. Printing Office), 453-474.

Williams, L. A., Crerar, D. A. 1985. Silica diagenesis, II. General mechanisms. J. Sediment. Petrol., 55, 312-321.

Date of initial receipt: 6 August 1987

Date of acceptance: 2 May 1988

Ms 104B-119 


\section{R. HENRICH}

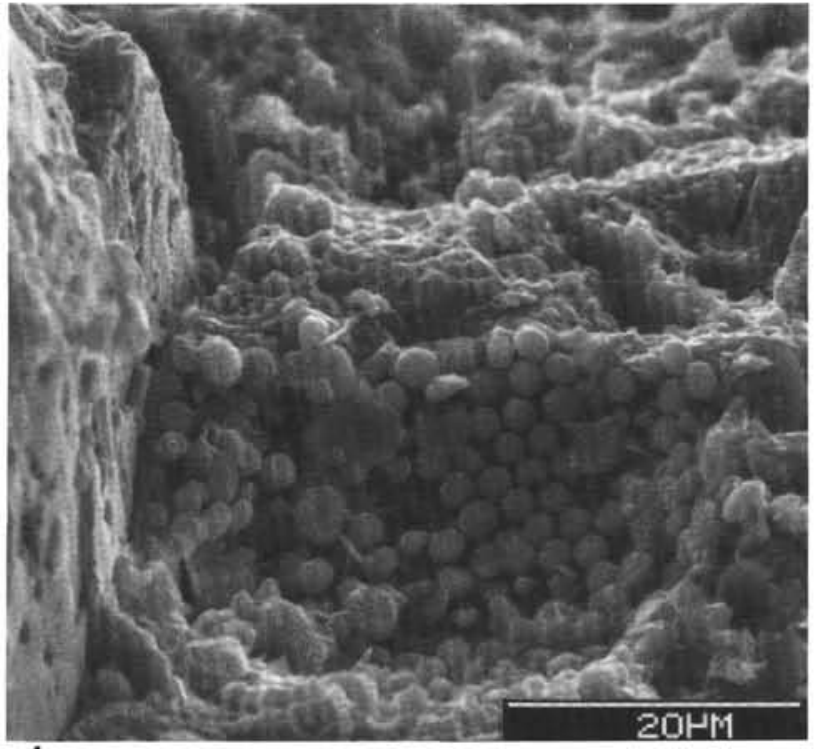

1

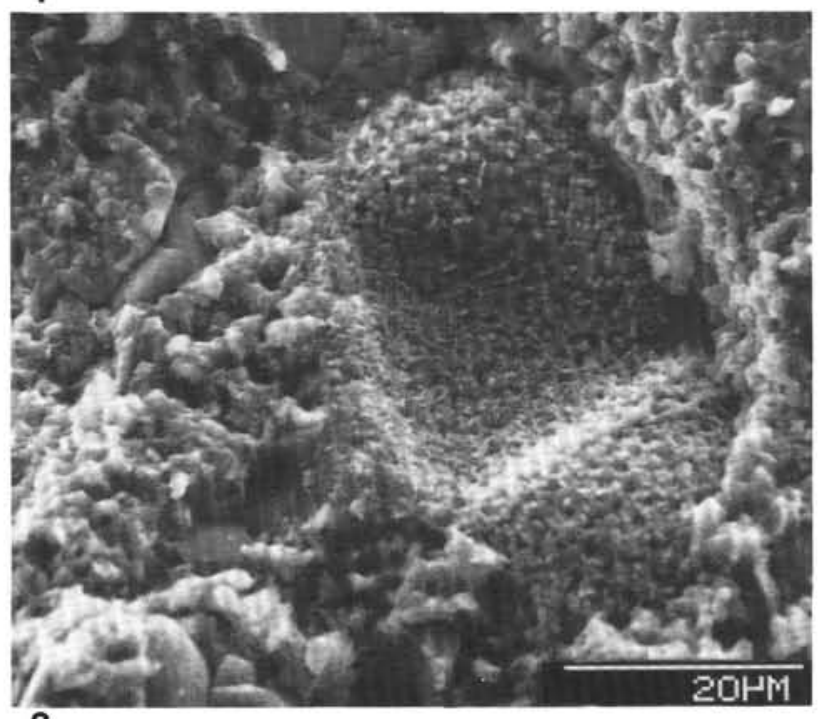

3

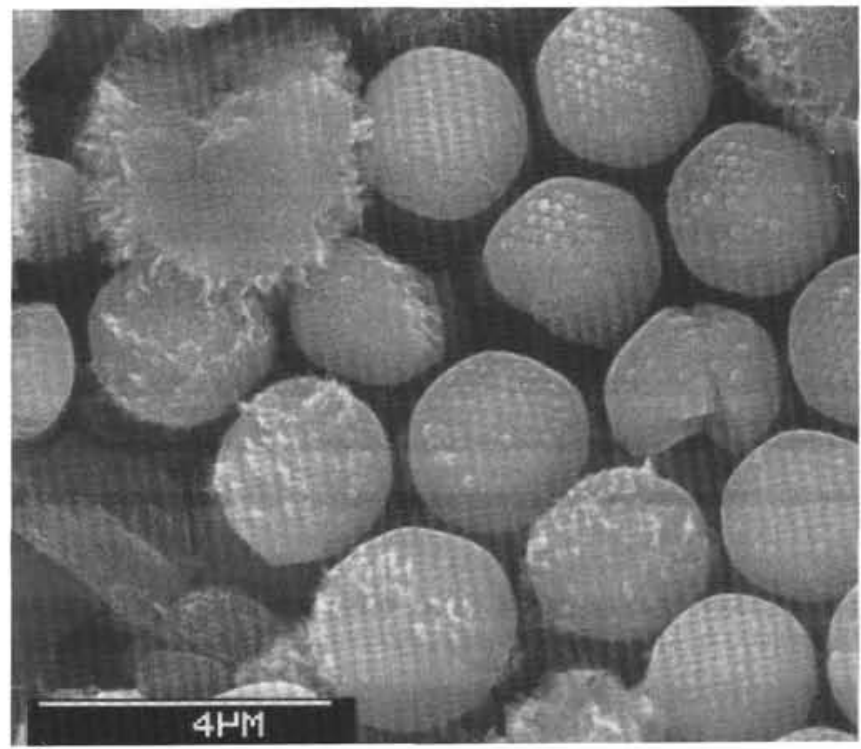

2

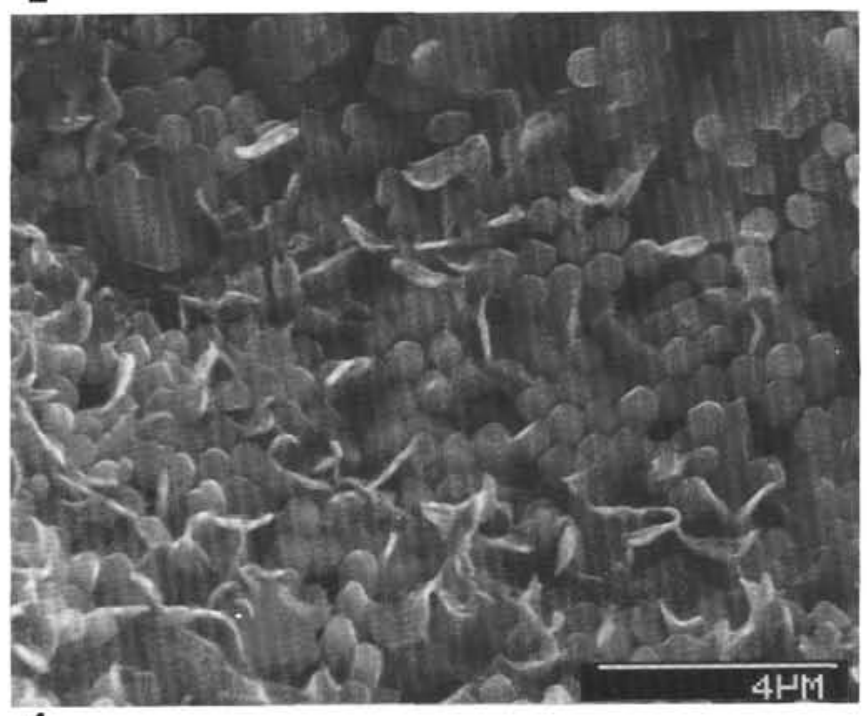

4

Plate 1. Preservation of delicate microstructures in casts of authigenic carbonate. 1, 2. Calcite molds of areolae of a diatom valve (Endictya spp.), which show the original cibrum structure (SEM-111329, -111330, Section 104-643A-41-CC, $38 \mathrm{~cm}, 382.38 \mathrm{mbsf}$ ). 3, 4. Diatom valve, Actinoptychus spp., replaced by Fe, Mn-calcite cement (3) with later overgrowth of tiny apatite crystals (4). (SEM-11646, -11647, Section 104-643A-32-CC, 12 cm, $297.84 \mathrm{mbsf})$. 

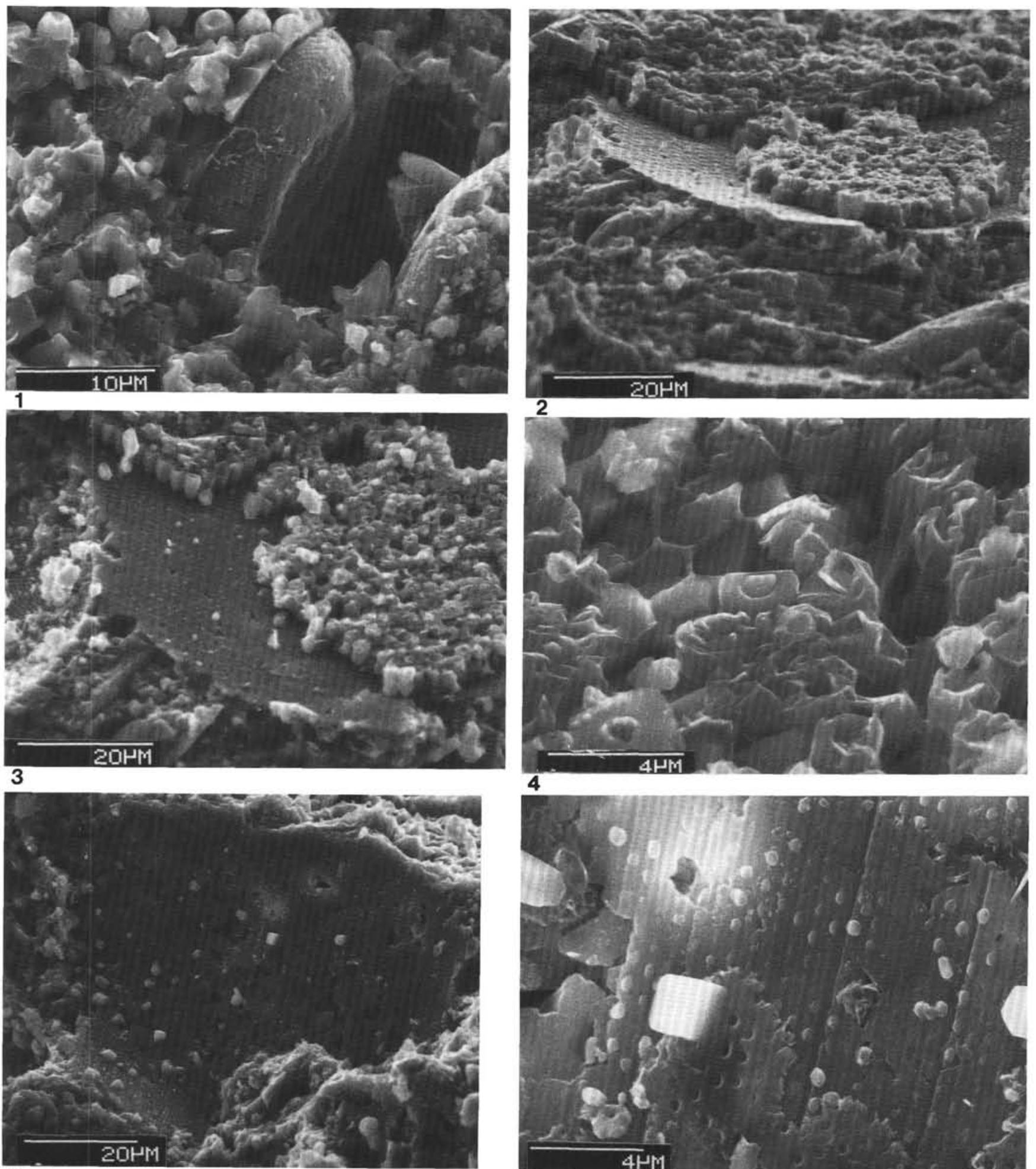

5

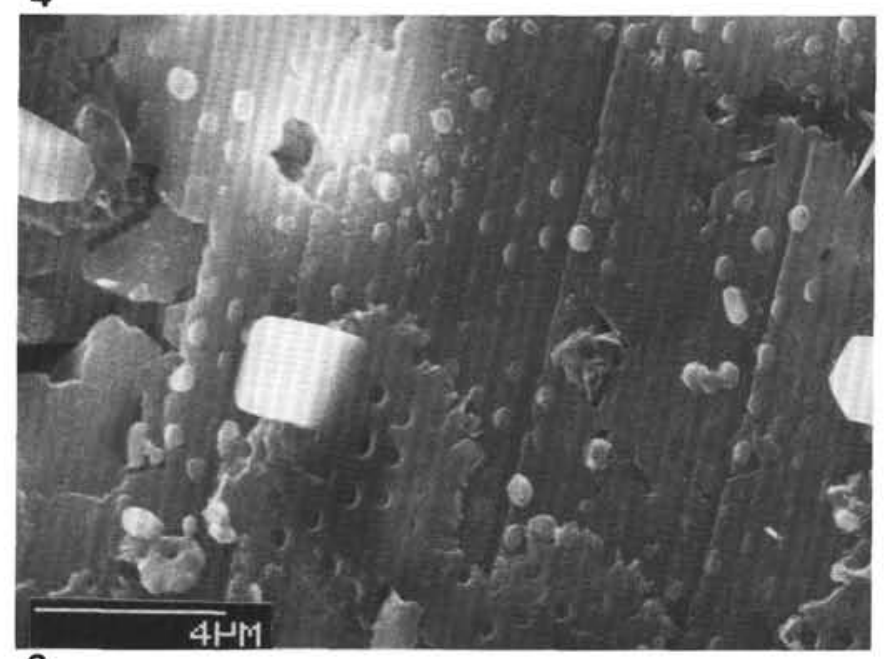

6

Plate 2. Outpourings of large centric diatom valves by primary authigenic Fe, Mn-calcite cement. 1. Diatom valve, Melosira spp., replaced by Fe, $\mathrm{Mn}$-calcite cement. The two valves seen in the center of the picture may be intact parts of a longer chain of valves (SEM-111648, Section 104-643A-32CC, $12 \mathrm{~cm}, 297.84 \mathrm{mbsf}$ ). 2. Endocasts of densely-packed large centric diatom valves by primary Fe, Mn-calcite cements (SEM-111635, Section 104-643A-32-CC, $12 \mathrm{~cm}, 297.84 \mathrm{mbsf}$ ). 3. Carbonate replaced top layer of diatom valve with carbonate casts (Fe, Mn-calcite cement) of areolae (SEM-111637, 111638, 297.84 mbsf). 4. Close-up of 3., showing perfect matching of Fe, Mn-calcite cements filling the pores between the top and the bottom layer of the valve. 5, 6. Close-up of large fragile valve of Ethmodiscus sp., completely unaffected by compaction (SEM-111317, Section $104-643 \mathrm{~A}-41-\mathrm{CC}, 38 \mathrm{~cm}, 382.38 \mathrm{mbsf})$. 

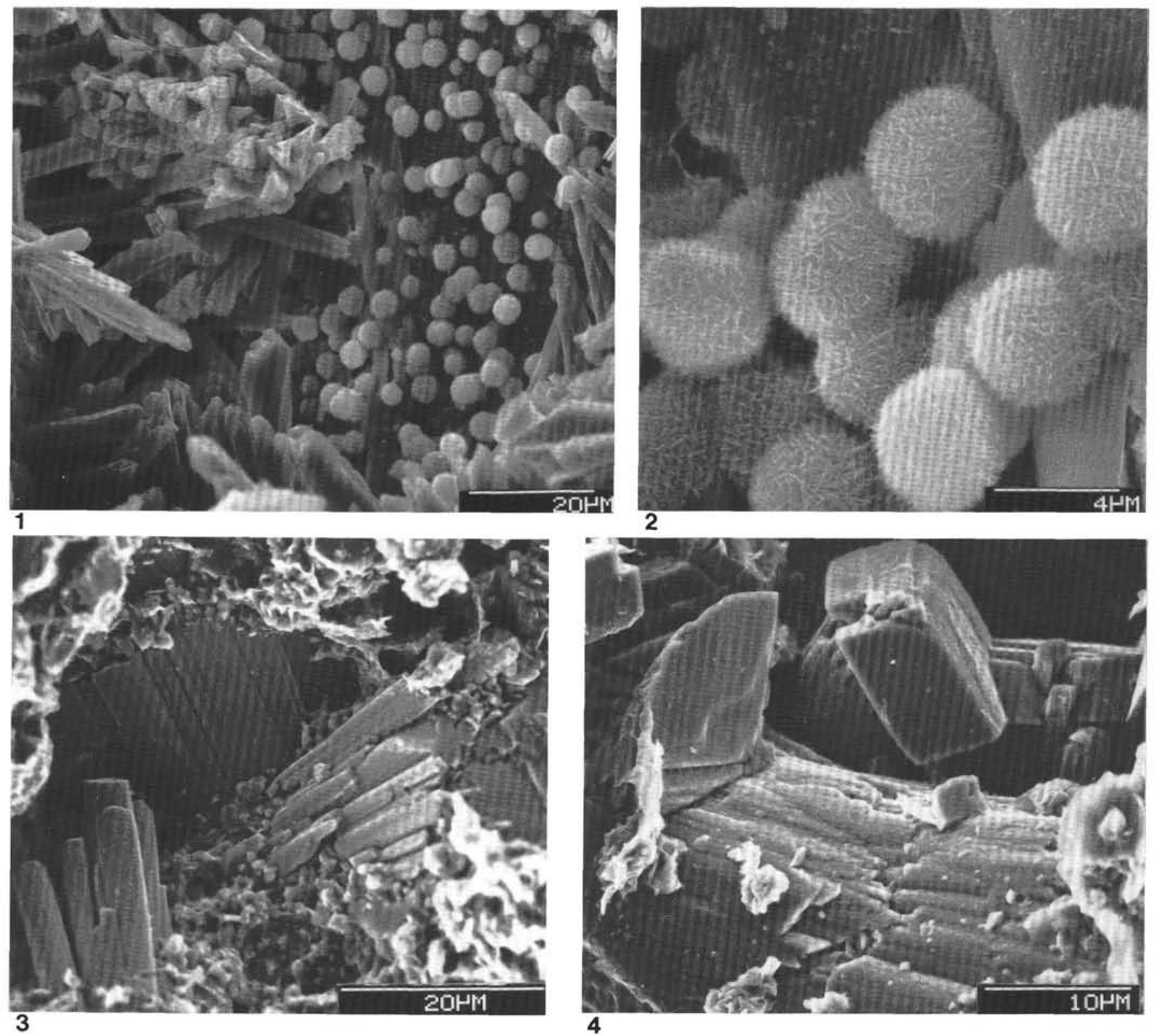

Plate 3. Rhodochrosites, aggregates of altered ash and later mineralization (secondary carbonate, opal-CT lepispheres). 1, 2. Siliceous microfossil replaced by primary carbonate; precipitation of later carbonate cements with long prismatic needles and opal-CT crystallization showing typical lepispheres (2. for detail) (SEM-111321, -111325, Section 104-643A-41-CC, $38 \mathrm{~cm}, 382.38 \mathrm{mbsf}$ ). 3. Late rhodochrosite replacing the matrix of a tuffaceous mudstone and precipitated within the pore space (SEM-113758, Section 104-643A-51-05, $105 \mathrm{~cm}, 484.75 \mathrm{mbsf}$ ). 4. Bundles of densely packed rods of Mn-rich aluminosilicates (EDAX: $\mathrm{Mn}, \mathrm{Ca}, \mathrm{Si}, \mathrm{Al}$ ), possibly representing a specific zeolite formed by early diagenetic alteration of tuffaceous matter (SEM-113288, Section 104-643A-51-05, $105 \mathrm{~cm}, 484.75 \mathrm{mbsf}$ ). 


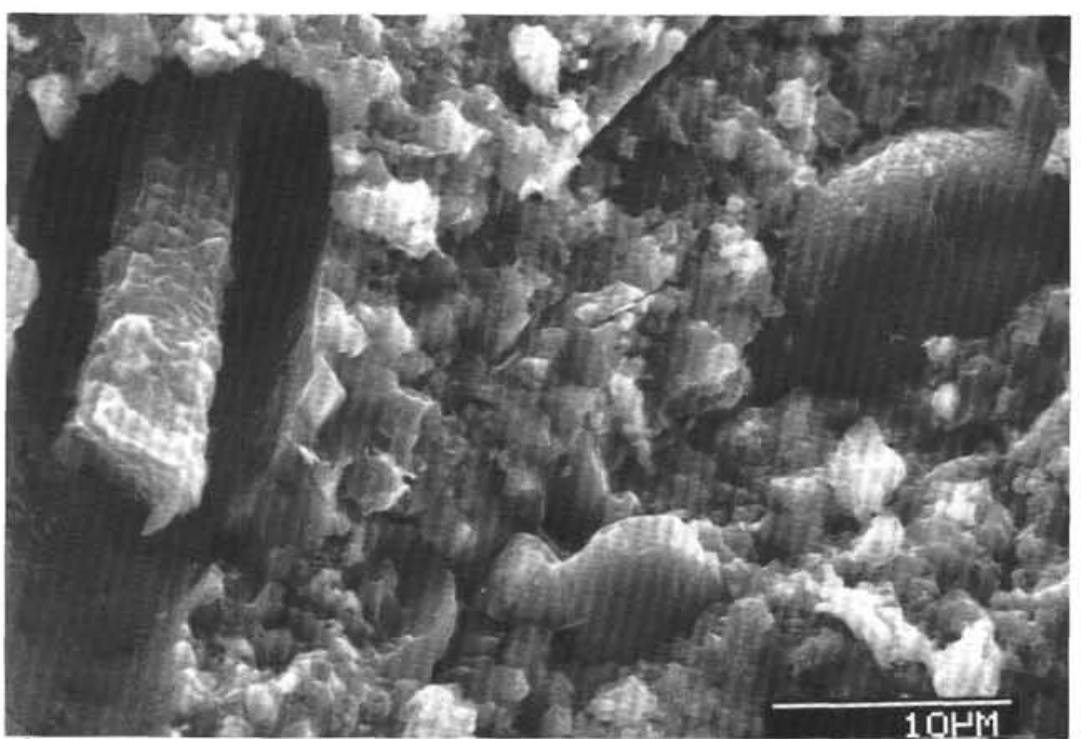

1

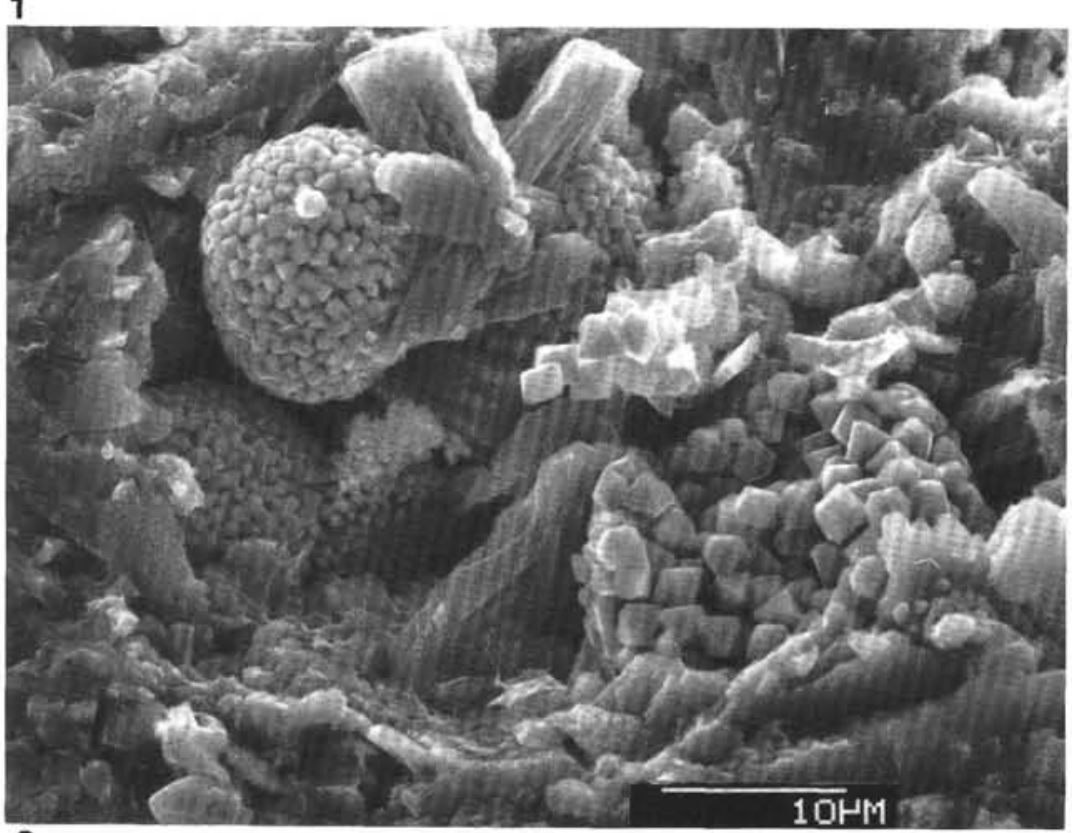

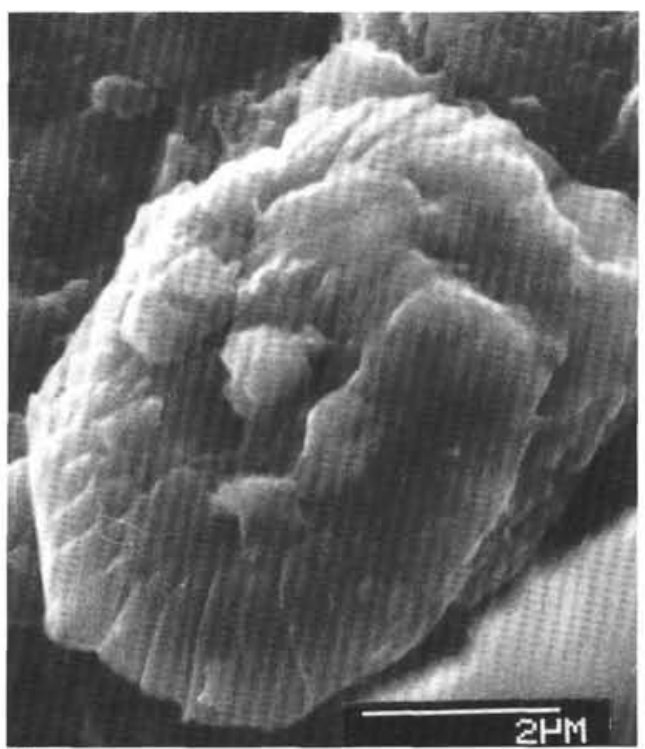

3

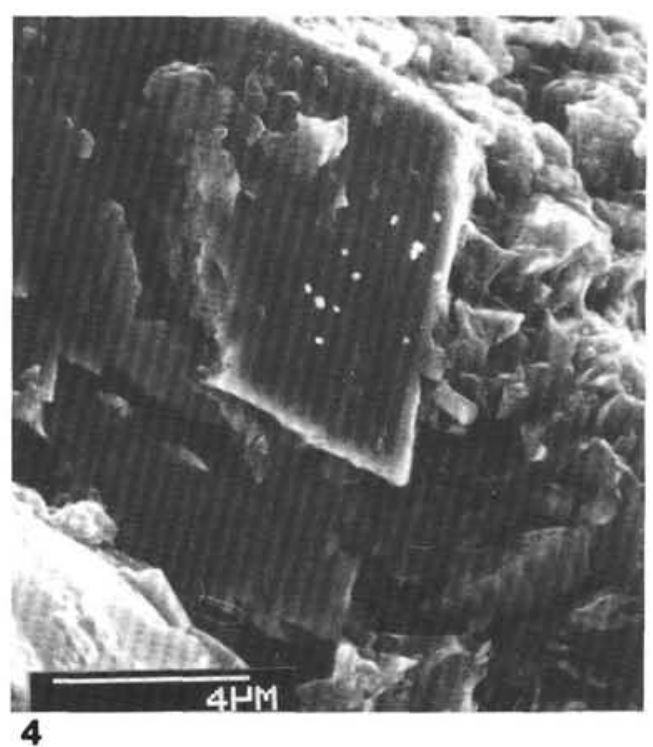

2

Plate 4. Recrystallized nannofossil-rich calcareous mudstones and sequence of early diagenetic mineralizations. 1. Casts of a sponge spicule filled by Fe, Mn-calcite cement and diatom valves of Melosira spp. embedded in a very fine-grained Fe, Mn-calcite micrite matrix. (SEM-111640, Section 104-643A-32-CC, $4 \mathrm{~cm}, 297.84 \mathrm{mbsf}$ ). 2. Primary carbonate replacing siliceous microfossils. Subsequent precipitation of framboidal pyrite, a second generation of carbonate and opal-CT (SEM-111334, Section 104-643A-32-CC, $4 \mathrm{~cm}, 297.84$ mbsf). 3. Badly preserved coccolith in a recrystallized micritic matrix (SEM-114892, Section 104-643A-42-CC, $40 \mathrm{~cm}, 400.40 \mathrm{mbsf}$ ). 4. Late Fe, Mn-calcite rhombs dispersed in a very fine-grained recrystallized micritic matrix containing coccoliths (SEM-114894, Section 104-643A-42-CC, $40 \mathrm{~cm}, 400.40 \mathrm{mbs}$ ). 